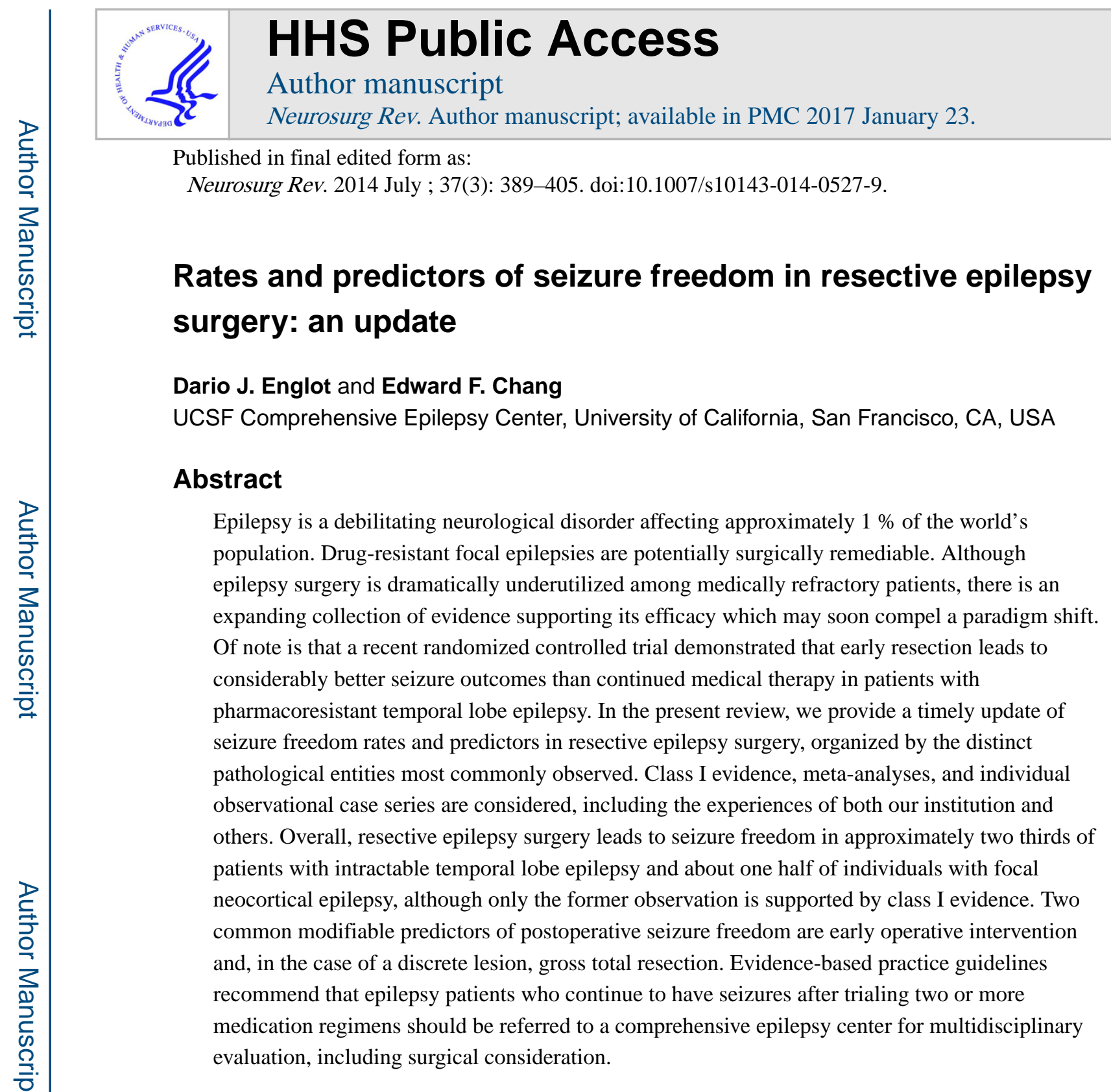

Keywords

Epilepsy surgery; Resection; Review; Seizure outcome

\title{
Introduction
}

\begin{abstract}
Epilepsy is a debilitating neurological disorder affecting approximately $1 \%$ of the world's population, producing a tremendous societal burden $[9,49]$. Though common, drug-resistant focal epilepsies are potentially surgically remediable. Perspectives related to epilepsy surgery have progressed considerably over the past several decades, as recently summarized by Wilson and Engel [210], with a few notable developments in just the past year. With
\end{abstract}

D. J. Englot, Department of Neurological Surgery, University of California, San Francisco, 505 Parnassus Avenue, Box 0112, M779, San Francisco, CA 94143-0112, USA, englot@gmail.com.

Disclosures The authors have no conflicts of interest to disclose. 
regard to palliative non-resective epilepsy surgery, the past 1-2 years have seen the approval of NeuroPace—a new implantable neurostimulation device for epilepsy [82] —as well as the 100,000 th implantation of a vagus nerve stimulator [44]. More importantly, however, Engel and colleagues [61] recently reported the much anticipated results of a randomized controlled trial investigating the clinical effectiveness of early resective epilepsy surgery in patients with temporal lobe epilepsy (TLE)61. Only the second randomized controlled trial to address resective epilepsy surgery, this study demonstrated convincingly that early surgical intervention in patients with newly refractory TLE produces better seizure outcomes than continued conservative drug therapy. Some have speculated whether this pivotal trial might facilitate a paradigm shift in the treatment of focal epilepsy [120, 174]. Specifically, whereas many practitioners have thus far been hesitant to consider invasive surgery for pharmacoresistant patients_-instead pursing years to decades of new medication combinations with marginal success-these novel data may influence earlier referral for surgical consideration $[62,102,127]$.

There is also reason to be skeptical that the findings of Engel and colleagues will stimulate any meaningful paradigm shift. After the first randomized controlled trial by Wiebe et al. in 2001 [207] revealed dramatically improved seizure outcomes with epilepsy surgery over medical therapy in refractory TLE patients207, consensus guidelines recommended early surgical referral of pharmacoresistant epilepsy patients [41, 62, 63, 128]. At that time, there was anticipation of an increase in surgical referrals [59], but large epilepsy centers did not experience the expected increase in patient volume [60, 102]. In fact, two studies in the past year examining US hospital data from the Nationwide Inpatient Sample-reported independently by our group and by Schiltz et al.- revealed no change in the utilization of epilepsy surgery during the 2000s, despite class I evidence and clear practice parameters [73, 173]. Furthermore, it was found that epilepsy patients are increasingly being treated at lowvolume community hospitals, rather than high-volume epilepsy centers, and that these smaller institutions are less likely to perform surgery [74]. It remains unclear whether new class I data supporting epilepsy surgery will significantly influence its persistent underutilization. Nevertheless, the recent refocus on the issue allows a timely opportunity for an inclusive update on seizure outcomes after epilepsy surgery, considering temporal lobectomy and other resective procedures.

In the present review, our goal is a concise but thorough summary of seizure freedom rates and predictors in the surgical treatment of epilepsy, with particular focus on class I evidence and our own institutional experiences. "Seizure freedom" will be defined as a lack of disabling seizures, or a class I seizure outcome using the grading scale by Engel and colleagues [57], and predictors of seizure freedom will refer to modifiable and fixed variables significantly associated with an Engel class I outcome. Both children and adults will be considered. Palliative non-resective epilepsy surgery, including disconnection procedures and neurostimulation device implantation, will not be discussed.

While most discussions of resective epilepsy surgery are organized by the lobe(s) harboring the epileptogenic zone, there are also important treatment nuances across the various neuropathological entities which cause focal epilepsy. Blumcke's recent analysis of 4,512 specimens excised during resective epilepsy surgeries—the largest study of its kind—allows 
insight into the commonality of these various pathological entities [18]. As reproduced in Table 1, mesial temporal sclerosis (MTS) was the most common clinicopathological finding observed (40\%), followed by brain tumors ( $27 \%$ ), malformations of cortical development (MCD, $13 \%$ ), and vascular malformations (6\%). Henceforth in this review, we will consider focal epilepsy etiologies in this same order.

\section{Mesial temporal sclerosis and temporal lobe epilepsy}

TLE is the most common epileptic disorder, first described in detail by Hughlings-Jackson in the late nineteenth century $[65,111]$. Hughlings-Jackson suspected a mesial temporal origin of the "uncinate fit" and its resultant "dreamy state," a phenomenon now recognized as the characteristic complex partial seizure of TLE, and its effects on higher-order association cortex involved in consciousness $[68,78,109,111]$. While a wide variety of lesions in the mesial or lateral temporal lobe can lead to mesial or lateral TLE, respectively, the most common pathology underlying intractable TLE is MTS [18, 182]. MTS is characterized by neuronal loss, cellular reorganization, and glial proliferation in the hippocampus and may also be associated with sclerosis of the amygdala and parahippocampal gyrus [189]. It has been proposed that these and other changes lead to hyperexcitability of dentate granule cells, which spread out of the hippocampus to generate seizures [46]. Potential risk factors for developing TLE have been described and may include febrile seizures, head trauma, central nervous system infection, family history of epilepsy, alcohol or drug abuse, status epilepticus, birth injury, cerebral ischemia, and other temporal lobe lesions $[84,87]$.

In TLE, seizures are refractory to antiepileptic drugs (AEDs) in approximately $30 \%$ of patients, leading to cognitive deficits, reduced quality of life, and increased risk of death [34, $60,105]$. Selecting appropriate candidates for temporal lobe resection requires comprehensive neuroimaging, electrophysiological, and neurocognitive evaluation by a team of neurologists, neuropsychologists, neurosurgeons, and neuro-radiologists. High-resolution structural magnetic resonance imaging (MRI) to evaluate for MTS or other lesions is routine, and functional neuroimaging may include positron emission tomography (PET) to search for focal hypometabolism and functional MRI or magnetoencephalography to localize language and, in some cases, interictal spikes [16, 31, 112]. At several centers, functional neuroimaging is replacing invasive WADA testing for language lateralization, but WADA remains the gold standard for memory lateralization $[1,16]$. Interictal scalp electroencephalography (EEG) is often followed by longer periods of inpatient video EEG monitoring, and invasive intracranial EEG with grid, depth, and strip electrodes is used when localization of the epileptogenic zone remains in question and/or greater spatial detail is required [91, 220]. In some instances, intraoperative electrocorticography (ECoG) can be used to supplement or replace long-term intracranial EEG, particularly in patients undergoing awake speech mapping, although capturing ictal events requires implanted electrodes [11, 161]. Notably, the evaluation of extratemporal epilepsy absent a pre-localized lesion often incorporates a similar diagnostic strategy [165].

The standard of care in treating drug-resistant TLE from MTS is resective surgery with anterior temporal lobectomy (ATL) [58, 97, 182]. In both adults and children, seizure 
freedom is more common after resection for MTS (60-90\%) than localized neocortical epilepsies (40-70\%), the most common being frontal lobe epilepsy [69, 75, 77]. In our own surgical series including the past 15 years, approximately $70-80 \%$ of adults and children with TLE have achieved seizure freedom after ATL $[72,76]$. Furthermore, resective TLE surgery has been validated by class I evidence through two randomized controlled trials. In the first of these trials, Wiebe and colleagues [207] found that 40 drug-resistant TLE patients who underwent ATL were significantly more likely to be seizure-free at 1 year $(58 \%)$ than 40 patients randomized to continued best drug therapy ( $8 \%$ seizure-free)207. In a metaanalysis including this trial and 31 other studies (2,250 patients), Engel et al. [63] reported that $65 \%$ of TLE patients achieved seizure freedom after ATL, with another $21 \%$ experiencing an improved seizure profile63. Together, these results led to a joint recommendation of the American Academy of Neurology, the American Epilepsy Society, and the American Association of Neurological Surgeons that patients with medically refractory epilepsy be referred to a comprehensive epilepsy center with surgical capabilities [63].

Recently, in a second randomized controlled trial comparing ATL to continued AED therapy, Engel and colleagues [61] specifically investigated the value of early surgical intervention61. They found that while $73 \%$ of 15 surgically treated individuals were seizure-free at 2 years, none of the 23 patients assigned to medical therapy reached this outcome. Furthermore, improvements in quality of life were significantly greater in the surgical group than the medical group. Overall, the data in favor of surgical resection for appropriate candidates with intractable TLE-including two randomized controlled trials and numerous observations studies-are convincing and suggest that a surgical "cure" is possible in some patients with this devastating disorder.

With regard to operative approach for mesial temporal lobe resection, most studies have shown comparable seizure outcomes between standard ATL and selective amygdalohippocampectomy (AH) [175, 215], although the latter may carry the risk of seizure recurrence in patients with an unrecognized lateral temporal epileptogenic zone [153]. While many groups have described improved memory outcomes and neuropsychological scores with selective AH over ATL [35, 142], others have reported no differences [24, 96, 212]. Finally, with careful operative technique, some authors have proposed that visual field deficits may be less pronounced with selective AH over standard ATL [136, 192].

\section{Brain tumors}

A brain tumor is the second most common cause of focal epilepsy. Tumor-related epilepsy may lead to diminished quality of life, cognitive deterioration, and significant morbidity $[169,179,187,221]$. While the molecular mechanisms of epileptogenicity in brain tumors remain incompletely understood, pathophysiological contributions include cerebral hypoxia, neurotransmitter alterations, and disruption of the blood-brain barrier [64, 100, 119, 169, 178]. While seizures can be caused by intrinsic intra-axial tumors, metastatic tumors, or extra-axial tumors (such as meningioma), glioneuronal tumors and gliomas are the most common pathologies associated with tumoral epilepsy, and will be the subject of our focus. 


\section{Glioneuronal tumors}

Unlike patients with malignant brain tumors, patients with low-grade tumors often survive many years $[155,156]$, making seizure freedom a critical factor in optimizing patient quality of life. Among low-grade brain tumors, glioneuronal tumors such as gangliogliomas and dysembryoplastic neuroepithelial tumors (DNETs) are most likely to present with seizures [27, 94, 141, 147]. Approximately three quarters of ganglioglioma patients present with seizures, three quarters of those have a temporal lobe lesion, and nearly half of patients with ganglioglioma progress to drug-resistant epilepsy $[4,131,181]$. With DNET, approximately half of epilepsy patients harboring this lesion also have associated cortical dysplasia [27].

Previous studies have examined seizure outcomes in the resection of glioneuronal tumors causing epilepsy, reporting postoperative seizure freedom rates of between 45 and $100 \%$ [4, $27,92-94,152,214]$. In a recent retrospective series of 66 patients with ganglioglioma treated at our center, 49 of which presented with epilepsy, we evaluated long-term seizure outcomes after excision [181]. Five years after resection, $85 \%$ of patients with a seizure history were free of seizures, including $96 \%$ of individuals in whom gross total lesionectomy was achieved, but only $54 \%$ of those with subtotal resection. Tumor progression occurred in $38 \%$ of cases involving gross total resection, but in only $8 \%$ of those associated with subtotal resection. We also evaluated 50 patients with DNET-related epilepsy surgically treated at our institution, $87 \%$ of whom reached an Engel class I outcome after surgery [27]. Seizure freedom was again predicted by gross total resection, achieved in approximately $80 \%$ of surgeries, and this outcome remained resilient at a median follow-up of $>5$ years [27]. The positive predictive value of extent of resection in glioneuronal tumor-related epilepsy surgery was also confirmed by a systematic review of 39 studies including 910 patients [67]. In this report, seizure freedom was $>30 \%$ more likely with gross total resection compared to subtotal excision and was also predicted by an absence of generalized seizures and early surgical therapy. Overall, these findings suggest that both seizure and oncologic outcomes can be excellent in glioneuronal tumor surgery, particularly with complete resection and early operative intervention.

\section{Gliomas}

World Health Organization grade II gliomas-including astrocytoma, oligodendroglioma, and oligoastrocytoma - are invasive lesions that often progress over time despite therapy $[12,28]$. Seizure generation in gliomas may result in part from invasion of tumor cells into surrounding brain parenchyma as well as increased expression of fast-activating sodium channels and diminished potassium buffering within glial cells at the epileptogenic foci [20, 166]. While the oncological prognosis of gliomas is poorer than glioneuronal tumors, lowgrade glioma patients may nonetheless survive $>10$ years with aggressive management, and seizure control is a known factor in maximizing quality of life [53, 121, 186, 195].

$20,16653,121,186,195$ Seizures are a common presenting symptom in patients with lowgrade glioma, affecting $60-80 \%$ of individuals with these lesions [158, 160, 219]. In an analysis of 332 low-grade glioma patients undergoing resection at our center, $80 \%$ presented with seizures, and pharmacoresistance was present in half of these [32]. Seizure freedom was seen in $67 \%$ of individuals with tumoral epilepsy after surgery, with rare 
seizures observed in another $17 \%$, and favorable outcomes were predicted by greater extent of resection. Lesion recurrence was associated with epilepsy recurrence, further demonstrating the association between tumor burden and seizures [32]. A recent systematic review of the literature examined 773 patients with low-grade gliomas and epilepsy across 20 surgical series [66]. It was noted that about $70 \%$ of individuals with low-grade gliomarelated epilepsy become seizure-free after surgery, with predictors of this outcome including resection extent (defined as removal of tissue displaying abnormal $\mathrm{T} 2$ signal on postoperative compared to preoperative MRI), a shorter history of epilepsy, and preoperative seizure control on AEDs. Thus, as with glioneuronal tumors, improved seizure outcomes in low-grade glioma surgery are seen with early intervention and gross total resection, and a direct relationship between tumor burden and seizure status is likely.

High-grade gliomas are associated with a much poorer prognosis than low-grade lesions, with median survival of approximately 22 months for anaplastic astrocytoma and 12 months for glioblastoma, even with surgery, radiation, and chemotherapy [23, 42, 47, 67]. Seizures affect between 25 and $60 \%$ of individuals with high-grade gliomas and negatively impact quality of life [26, 95, 106, 139, 154]. To our knowledge, there has only been one study investigating seizure status as a primary outcome in high-grade glioma surgery. In this retrospective case series, 1 year after surgical resection of glioblastoma in 153 patients with epilepsy, $77 \%$ of individuals were seizure-free on medication [26]. A favorable postoperative seizure outcome was predicted by preoperative seizure control. Nevertheless, given the poor oncological prognosis associated with high-grade gliomas, the primary goal of resection remains aggressive tumor control, with surgical treatment of seizures representing a worthwhile secondary consideration [67].

\section{Additional considerations with temporal lobe tumors}

While any supratentorial tumor can cause epilepsy, patients with temporal lobe lesions are particularly prone to seizures, like due to the epileptogenicity of mesial temporal structures $[32,88,203]$. It is known that seizure freedom in tumor surgery is more common with gross total resection than subtotal lesionectomy, but an additional consideration in tumoral TLE is that dual pathology may drive ictogenesis [84, 182]. Thus, cortical dysgenesis, gliosis, and hippocampal sclerosis may permit continued seizures even after gross total excision of the primary lesion $[84,88,203]$. Some investigators have therefore argued for more extensive resection in tumor-related TLE cases, suggesting that the inclusion of hippocampectomy and anterior temporal corticectomy produces better postoperative seizure control than gross total lesionectomy alone [14, 94, 117, 148]. In such cases, perilesional parenchymal resection is often customized by interictal spike mapping via intra-operative ECoG recordings [12, 181]. In one study, Giulioni and colleagues [94] retrospectively analyzed seizure outcomes in 28 patients who received tailored surgery for temporal lobe glioneuronal tumors causing epilepsy94. One half of the patients underwent lesionectomy alone, while the other half received lesionectomy along with customized amygdalohippocampectomy and anterior temporal corticectomy. Seizure outcomes were dramatically better in individuals who received extended resection (93\% Engel I) compared to lesionectomy alone (43\% Engel I), but other differences between patients in either group may have confounded this finding. We recently meta-analyzed extent of resection in low-grade temporal lobe tumor resections 
across 41 studies including 1,181 patients [70]. Subtotal lesionectomy alone produced a postoperative seizure freedom rate of only $43 \%$, versus $79 \%$ with gross total lesionectomy alone, versus $87 \%$ with lesionectomy plus hippocampectomy and/or anterior temporal corticectomy [70]. The small but significant benefit of extended resection over gross total lesionectomy alone appears more prominent with mesial rather than lateral temporal lesion location. It is therefore possible that a larger tailored resection may be associated with better seizure outcomes in temporal lobe tumoral epilepsy surgery, but consensus recommendation would likely require controlled prospective data.

\section{Malformations of cortical development}

MCD represent a spectrum of congenital structural abnormalities of cerebral cortical growth and development. MCD range in severity from focal cortical dysplasia (FCD) to polymicrogyria and are a major cause of pharmacoresistant epilepsy [33, 151, 199]. MCD subtypes can result from abnormal (1) neuronal and glial proliferation or differentiation, (2) neuronal migration, or (3) cortical organization [130]. MCD resulting from aberrant cellular proliferation or differentiation are the most common, and under the most recent classification scheme, these include FCD, tuberous sclerosis, and hemimegalencephaly [3, 7, 130]. Epilepsy is also seen in MCD involving neuronal migration problems (lissencephaly, subcortical band heterotopia, periventricular nodular heterotopia) and abnormal cortical organization (polymicrogyria, schizencephaly), but these disorders will not be discussed here further given their relative rarity.

\section{Focal cortical dysplasia}

FCD can be defined using a three-tier system recently updated by the International League Against Epilepsy (ILAE) Task Force [19], as summarized in Table 2 [19]. Seizures are the most common presentation of FCD, and approximately one half of all epilepsy patients have some form of FCD [17]. The mechanisms of ictogenesis in FCD have been investigated in humans and animal models. These include increased excitation in dysplastic neurons produced by elevated glutamate receptor expression $[38,48,108]$ as well as diminished neuronal expression of $\gamma$-aminobutyric acid (GABA) receptors within FCD lesions [83, $183]$.

Resection for FCD-related epilepsy can be challenging as subtle radiographic anomalies can produce devastating epileptic syndromes [36]. Rates of seizure control reported in the literature range widely from 32 to $89 \%$ after resection $[33,103]$. In a recent surgical series of 143 patients with FCD and intractable epilepsy at our institution, postoperative seizure freedom rates were $72 \%$ at 2 years, $65 \%$ at 5 years, and $67 \%$ at 10 years [33]. The main predictor of seizure outcome was gross total resection delineated by both MRI and invasive ECoG recordings [33]. Other positive prognosticators included small lesion size and a focal gray-white blurring on MRI known as the transmantle sign [198]. In a meta-analysis combining these results with 36 other surgical FCD series, postoperative seizure freedom was achieved by $58 \%$ of 2,014 patients [168]. Favorable outcome was predicted by temporal lobe surgical location, abnormal MRI, type II ILAE histological classification, and complete resection of the anatomical or electrographic abnormality. Given the inherent 
challenge of accurately delineating the ictogenic zone in FCD, these findings highlight the importance of high-resolution neuroimaging, meticulous electrophysiological techniques, and histopathologically proven margins in guiding the surgical excision of dysplastic lesions.

\section{Tuberous sclerosis}

Tuberous sclerosis complex is an autosomal dominant disorder resulting from mutations in the gene TSC1 (encoding hamartin) or TSC2 (encoding tuberin), leading to the formation of hamartomas and other neoplasms in multiple organ systems [40, 133]. This condition was first described in detail by Bourneville in 1880 and has an overall prevalence of approximately 1 person per $6,000[21,40]$. Seizures are the manifesting symptom in $90 \%$ of patients with tuberous sclerosis, often beginning in the first year of life [80]. The pathogenesis of epilepsy is incompletely understood, but has been suggested to involve abnormal GABA receptor expression and impaired glutamate transport in astrocytes [80, 204, 213].

Seizures become refractory to AEDs in the majority of children with tuberous sclerosis by 2 years of age, leading to marked cognitive impairment and developmental retardation [43, 80, $99,113]$. Therefore, early surgical intervention is often considered for patients with severe pharmacoresistant epilepsy [80]. However, bilateral or multiple epileptogenic foci are more common in tuberous sclerosis than other lesional epileptic disorders, perhaps given the frequent multiplicity of parenchymal tubers $[25,164,202]$. Therefore, the appropriate selection of surgical candidates requires meticulous preoperative evaluation with highresolution neuroimaging and electrophysiologic recordings and often includes invasive intracranial recordings $[25,80]$.

Seizure outcome data for tuberous sclerosis surgery are somewhat limited as most published patient cohorts are small and retrospective. However, two independent systematic reviews have helped to summarize relevant cases throughout the literature. Jansen et al. [114] examined 25 articles including 177 epilepsy patients receiving resective surgery for tuberous sclerosis114. After post-surgical follow-up of $\geq 1$ year, patients experienced a $90 \%$ decrease in seizure frequency, with $57 \%$ of individuals becoming seizure-free. Similar seizure outcomes were reported in a recent meta-analysis by Fallah and colleagues [81], who analyzed 181 resections from 20 studies with a median follow-up of 2.3 years81. Overall, $56 \%$ of patients reached an Engel class I outcome, with significant negative prognosticators including generalized seizures, developmental delay, and multifocal abnormalities on electrographic or neuroimaging studies. Thus, while bilateral or multiple epileptogenic foci may make the surgical treatment of tuberous sclerosis challenging, seizure freedom can nonetheless be achieved in over half of carefully selected patients with careful preoperative evaluation.

\section{Hemimegalencephaly and other causes of catastrophic hemispheric epilepsy}

First described by Sims in 1835, hemimegalencephaly is a rare form of MCD involving abnormal proliferation of dysplastic neuronal and glial cells, leading to hypertrophy of the affected cerebral hemisphere $[6,50,180]$. It is found in approximately $0.1-0.3 \%$ of epileptic children, but the pathogenesis remains largely unknown $[50,115]$. Macrocephaly is 
commonly the only physical finding in children with hemimegalencephaly, but hemigigantism and/or neurocutaneous lesions may be seen in syndromic variants [85]. Most children with this disorder develop a severe, progressive, and medically refractory epilepsy syndrome within the first 6 months of life, usually associated with marked cognitive and psychomotor impairments including contralateral hemiparesis and hemianopia [193]. Seizure types include partial motor seizures, tonic and atonic seizures, spasms, and myoclonic jerks [50, 122]. Thus far, surgical removal (anatomic hemispherectomy) or multifocal disconnection (functional hemispherectomy or hemispherotomy) of one brain hemisphere remains the most useful albeit radical treatment option for severe hemimegalencephaly to prevent further seizures, cognitive decline, and premature death [85].

Among children who receive hemispherectomy for severe hemispheric epilepsy, hemimegalencephaly accounts for $30-50 \%$ of the cases [51, 116]. Other etiologies of catastrophic hemispheric epilepsy include Rasmussen encephalitis, Sturge-Weber syndrome, intracerebral hemorrhage, ischemic stroke, traumatic brain injury, and other cortical malformations [138]. Hemispherectomy was first described by Dandy in 1928 for glioblastoma resection and by McKenzie in 1938 for epilepsy treatment [45, 135]. In 1973, Rasmussen [159] proposed modifying the traditional anatomic hemispherectomy to reduce morbidity associated with hydrocephalus and blood loss, which at the time were thought to result from "superficial hemosiderosis." 159While several variations of functional hemispherectomy or hemispherotomy have since been described, and there is some inconsistency in the use of these terms among authors, the procedure typically involves a large central resection and temporal lobectomy plus callosotomy and disconnection of the frontal and parieto-occipital residual brain [86, 138, 146, 159]. Overall, 70-85\% children who receive hemispherectomy for hemimegalencephaly or another epileptogenic hemispheric condition achieve seizure freedom $[2,50,176]$. Functional hemispherectomy is associated with comparable early seizure outcomes with less morbidity than anatomical hemispherectomy, but late seizure recurrence may be more likely with a less extensive procedure [37, 86, 98].

Moosa and colleagues [138] recently published a single-institution experience of 170 hemispherectomy procedures in children with epilepsy, representing the largest such series to our knowledge138. Survival analysis revealed the probability of post-surgical seizure freedom to be $76 \%$ at 1 year and $63 \%$ at 5 years, with $66 \%$ of children reported as seizurefree at last follow-up (mean, 5.3 years). Bilateral PET abnormalities predicted early seizure recurrence, and there was no perioperative mortality. Complications were not investigated by Mossa et al., but are typically more common with hemispherectomy compared to more focal epilepsy resections [51]. Adverse outcomes may include worsened hemiparesis, hemianopia, or language function and the need for ventriculoperitoneal shunting [51, 86, 159]. However, because hemispherectomy is most often performed in children suffering from marked hemiparesis and hemianopia, the additional deficits incurred through surgery are generally low $[51,86,206]$. In certain cases of likely hemispheric epilepsy, one challenging decision is whether to perform focal resection only in order to limit surgical morbidity or proceed directly to hemispherectomy in order to increase the likelihood of seizure freedom. Several factors should be weighed, including severity of illness, radiographic and electrographic 
findings, patient age and capacity for neural remodeling, baseline neurological deficits, and the results of family discussions. Given the progressive neurological insult caused by persistent seizures, and the greater potential for recovery in a young plastic brain, early hemispherectomy/ hemispherotomy remains a valuable treatment option in children with intractable hemispheric epilepsy.

\section{Vascular malformations}

Vascular malformations of the brain, particularly cavernous malformations and arteriovenous malformations, are commonly associated with epilepsy [71, 79]. Indications for surgical resection include the prevention of intracranial hemorrhage and/or the treatment of medically intractable seizures. While a few case reports have proposed occasional ictogenesis with other cerebral vascular malformations, such as developmental venous anomalies and capillary telangiectasia [137, 172, 185], these lesions are not typically associated with epilepsy and will not be considered further.

\section{Cavernous malformations}

Cerebral cavernous malformations (i.e., cavernomas) are endothelial-lined vascular lesions comprising dilated blood-filled sinusoids without intervening brain parenchyma and may be associated with intracranial hemorrhage $[5,149,163]$. Seizures are the most common presenting symptom of supratentorial cavernomas, likely arising from the excitotoxic effects of blood products on perilesional brain tissue [196, 200, 209]. Overall, epilepsy affects 35-

$70 \%$ of patients with cavernous malformations, and about $40 \%$ of these individuals progress to pharmacoresistant epilepsy $[30,140,170]$. Most studies examining the surgical treatment of cavernomas focus on hemorrhage prevention, but clinically significant hemorrhage is not as common with these lesions as with brain arteriovenous malformations (AVMs) [124, 149, 162]. Thus, abolishing seizures is an important and often underappreciated goal in managing these lesions, given the morbid effects of intractable lesional epilepsy.

Our group performed a retrospective cohort study of 164 individuals receiving microsurgical resection of supratentorial cavernomas, of whom $62 \%$ presented with seizures and $35 \%$ had pharmacoresistant epilepsy [30]. Seizures were more common in patients with a temporal lobe lesion and, interestingly, the absence of symptomatic hemorrhage. Among the 44 patients with intractable epilepsy, $73 \%$ were entirely seizure-free after surgery, with another $11 \%$ reporting only rare seizures. Predictors of complete seizure freedom were gross total resection, smaller lesion diameter, and the absence of secondarily generalized seizures [30]. Comparable outcomes at other centers are reflected by a recent systematic review of 31 studies including 1,226 patients with surgically resected supratentorial cavernomas [71]. Overall, $75 \%$ of patients were seizure-free after microsurgical resection, and modifiable predictors of this outcome included gross total resection, earlier surgical intervention, smaller lesions, preoperative seizure control with AEDs, a lack of multiple cavernomas, and a history of partial seizures only [71].

While the benefits of gross total resection in cavernoma surgery are clear, one controversy regarding extent of resection remains; that is, whether or not to excise the hemosiderinstained parenchyma that surrounds the cavernoma, given the potential that this area may 
represent the true epileptogenic zone $[8,22,101,184,218,222]$. Some groups have described improved seizure outcomes with extended lesionectomy including this hemosiderin ring $[8,101,184]$, while others have found no additional benefit with adding adjacent corticectomy to lesionectomy alone [30, 71, 218, 222]. Given these conflicting reports, and the theoretical potential for additional morbidity with extended corticectomy, additional prospective data regarding this issue will be important.

\section{Arteriovenous malformations}

Brain AVMs are vascular lesions comprising tortuous anastomotic arteries and veins in cerebral parenchyma without intervening capillaries, resulting in arteriovenous shunting at a central nidus [145, 208]. AVMs are the most frequent cause of intracranial hemorrhage in young adults and children $[15,167]$, and seizures are the second most common presenting symptom with these lesions $[90,191]$. The mechanisms of epileptogenesis in AVMs are not fully known, but have been proposed to include cerebral ischemia from neighboring arteriovenous shunting, hemosiderin deposition, gliosis, demyelination, and kindling of excitatory synapses $[125,129,191,211,216]$. Various authors have reported the incidence of epilepsy with brain AVMs as anywhere from 12 to $57 \%$ of patients $[39,107,110,118$, $123,143]$. Epilepsy is more likely in patients with a history of hemorrhage, with larger lesions, and with AVM location in the temporal or frontal lobes [39, 54, 79, 104, 110, 118, 157]. Lesional epilepsy in AVM patients leads to increased morbidity [90, 191], but this is often overshadowed by the clinical focus on predicting and preventing intracerebral hemorrhage [89, 144, 150, 208].

Several case series have examined rates of seizure outcomes in the surgical treatment of AVMs causing seizures, with Engel class I outcomes reported in 49-94\% of patients [79, $107,123,157,191,217]$. In a recent observational study of 440 patients with supratentorial AVMs undergoing resection at our institution, 130 (30\%) had preoperative seizures [79]. Among these patients, seizure was the presenting symptom in $98(75 \%)$ and led to medically refractory epilepsy in 23 patients (18\%). After a mean postoperative follow-up of 21 months, $93 \%$ of patients with preoperative seizures achieved freedom from disabling seizures, including $91 \%$ of those with pharmacoresistant epilepsy [79]. Overall, seizure control is an important though undervalued goal in AVM surgery, secondary only to the prevention of devastating intracranial hemorrhage.

\section{Commentary}

\section{Seizure freedom is frequently achieved in resective epilepsy surgery}

Drug-refractory epilepsy is associated with cognitive and neuropsychological deficits and diminished quality of life [60], and a $0.5-1 \%$ annual mortality rate $[182,190]$. In contrast, epilepsy surgery is associated with only $2 \%$ significant morbidity, such as surgical site infection or visual field deficit, and $0.24 \%$ total surgical mortality [182, 190, 205], and longer quality-adjusted life span [34]. Outcomes are more favorable in surgery for mesial TLE surgery than focal neocortical epilepsy and vary somewhat by epilepsy etiology. The four most common distinct pathological entities found in surgical epilepsy specimens are MTS, brain tumor, MCD, and vascular malformation. 
Table 3 provides a summary of seizure freedom rates and predictors across epilepsy etiologies and various subtypes. With regard to mesial TLE surgery, seizure outcome data are taken from randomized controlled trials. For other resective procedures, data reflect the findings of meta-analyses/systematic reviews of uncontrolled observational case series across the literature, where available. Overall, resective epilepsy surgery produces seizure freedom in about two thirds of patients with mesial TLE and in approximately one half of individuals with other focal epilepsy etiologies. While seizure freedom is reported more frequently in the surgical treatment of some lesions (e.g., vascular malformation, glioneuronal tumor) than others (e.g., focal MCD, glioma), direct comparison of these outcomes is precluded by an absence of prospective controlled studies and because the primary surgical goal may differ by pathology. For instance, while seizure freedom is the primary goal in surgery for MTS, seizure control may be secondary to oncologic treatment or hemorrhage prevention in glioma or AVM resection, respectively.

\section{The importance of gross total resection and early surgical intervention}

Certain predictors of seizure freedom in epilepsy surgery are commonly observed across various epilepsy etiologies (Table 3). They include MTS, gross total lesion resection, early operative intervention, localized and concordant MRI/ EEG findings, and lack of secondarily generalized seizures. Of these, extent of resection and time to surgery are potentially modifiable variables.

Subtotal lesionectomy increases not only the risk of continued seizures but also the risk of intracranial hemorrhage or oncologic progression in cases of vascular malformation or brain tumor, respectively $[32,70,79,188]$. Gross total resection may prove challenging with a lesion involving eloquent brain or located in a region that is difficult to access surgically, but various technological tools can facilitate this surgical endeavor. In certain patients, the use of direct cortical stimulation for invasive mapping of eloquent brain - including motor, sensory, and language regions-improves the ability to safely maximize resection $[29,171]$. Noninvasive neuroimaging techniques, such as white matter tract mapping with diffusion tensor imaging or functional gray matter localization with magnetoencephalograpy or functional MRI, may also help guide surgical planning [13, 52,134]. The use of intraoperative MRI to facilitate more aggressive resection has also been examined, with positive results reported in one randomized controlled study of glioma surgery [177]. Similarly, intraoperative MR angiography or invasive cerebral angiography has been proposed to guide complete microsurgical obliteration of AVMs, but these techniques have not been evaluated prospectively $[10,56]$. Nevertheless, despite the positive prognostic value of extent of resection in lesional epilepsy surgery, patient safety remains the primary surgical concern, and primum non nocere the guiding principle.

Early surgical intervention in drug-resistant epilepsy is associated with an increased likelihood of postoperative seizure freedom, and seizure freedom is the single most important predictor of quality of life in epilepsy [55, 132]. Early intervention is also important, however, to reduce the duration of persistent epilepsy and its damaging effects on the brain. Pharmacoresistant epilepsy is associated with progressive neuropsychological and cognitive deficits $[60,68,105]$, a $0.5-1 \%$ annual mortality rate, and a lifetime standardized 
mortality two to three times higher than the general population [182, 190, 205]. In contrast, resective epilepsy surgery is associated with approximately $2 \%$ significant morbidity and $0.24 \%$ total surgical mortality $[182,190,205]$, as well as improvement in overall life span, neuropsychological profile, and quality-adjusted life years [34, 197, 201]. With temporal lobectomy, the value of early surgical intervention has been validated by class I evidence as newly refractory TLE patients experience significantly improved seizure outcomes with early surgery compared to continued medical therapy [61]. Furthermore, it is now well established that focal epilepsy patients are unlikely to achieve seizure freedom with medication alone after the failure of two or more separate AED regimens, leaving little reason to delay surgical evaluation [61, 102, 126, 127]. Thus, evidence-based practice guidelines strongly encourage early referral of children and adults with epilepsy to a comprehensive epilepsy center for multidisciplinary medical and surgical evaluation [41, 62, $63,128]$.

\section{Limitations}

The goal of this manuscript was to provide a brief but broad overview of seizure freedom rates and predictors in resective epilepsy surgery by pathological entity. While a detailed examination of other endpoints in the surgical treatment of epilepsy - neuropsychological and cognitive outcomes, quality of life assessments, surgical complication rates, patient satisfaction, and medication discontinuation - is beyond the scope of this focused review, they remain critical considerations. Although we did not consider non-resective surgical therapies in this review, such as callosotomy or device implantation, these remain important palliative treatment options for individuals who are not candidates for definitive resection. Similarly, while alternative treatment options exist for some lesions discussed herein (e.g., stereotactic radiosurgery or endovascular embolization of an AVM), they are beyond the scope of our present focus. Next, a bias toward our own institutional proceedings is present in this review, intended to reflect our group's treatment experiences. However, a thorough and comprehensive evaluation of the literature was performed to ensure that our clinical results are comparable to those of other groups, and differences are described where applicable. Finally, only temporal lobectomy outcomes have been evaluated by randomized controlled trials, and all other results discussed here are the product of uncontrolled observational case series and, therefore, inherently prone to bias. Randomized controlled trials evaluating the efficacy of resective epilepsy surgery in focal neocortical epilepsy are critically needed.

\section{Conclusions}

Resective epilepsy surgery is a safe and effective treatment for patients with drug-resistant epilepsy harboring a localizable seizure focus. Surgery leads to seizure freedom in approximately two thirds of patients with mesial TLE and about one half of individuals with focal neocortical epilepsy, with the former statistic validated by two randomized controlled trials. While several factors are associated with seizure outcome in epilepsy surgery, two modifiable predictors of seizure freedom include early operative intervention and, in patients with a discrete lesion, gross total resection. Practice guidelines recommend that epilepsy patients experiencing persistent seizures after two or more medication trials should be 
referred to a comprehensive epilepsy center for multidisciplinary evaluation, including surgical consideration.

\section{Acknowledgments}

We would like to thank the practitioners of the UCSF Comprehensive Epilepsy Center for their tireless dedication to the patients and to advancing care.

\section{References}

1. Abou-Khalil B. An update on determination of language dominance in screening for epilepsy surgery: the Wada test and newer noninvasive alternatives. Epilepsia. 2007; 48(3):442-455. [PubMed: 17319925]

2. Althausen A, Gleissner U, Hoppe C, Sassen R, Buddewig S, von Lehe M, Schramm J, Elger CE, Helmstaedter C. Long-term outcome of hemispheric surgery at different ages in 61 epilepsy patients. J Neurol Neurosurg Psychiatry. 2012; 84:529-536. [PubMed: 23268362]

3. Aronica E, Becker AJ, Spreafico R. Malformations of cortical development. Brain Pathol. 2012; 22(3):380-401. [PubMed: 22497611]

4. Aronica E, Leenstra S, van Veelen CW, van Rijen PC, Hulsebos TJ, Tersmette AC, Yankaya B, Troost D. Glioneuronal tumors and medically intractable epilepsy: a clinical study with long-term follow-up of seizure outcome after surgery. Epilepsy Res. 2001; 43(3):179-191. [PubMed: 11248530]

5. Awad I, Jabbour P. Cerebral cavernous malformations and epilepsy. Neurosurg Focus. 2006; 21(1):e7.

6. Barkovich AJ, Chuang SH. Unilateral megalencephaly: correlation of MR imaging and pathologic characteristics. AJNR Am J Neuroradiol. 1990; 11(3):523-531. [PubMed: 1693466]

7. Barkovich AJ, Kuzniecky RI, Jackson GD, Guerrini R, Dobyns WB. Classification system for malformations of cortical development: update 2001. Neurology. 2001; 57(12):2168-2178. [PubMed: 11785496]

8. Baumann CR, Schuknecht B, Lo Russo G, Cossu M, Citterio A, Andermann F, Siegel AM. Seizure outcome after resection of cavernous malformations is better when surrounding hemosiderin-stained brain also is removed. Epilepsia. 2006; 47(3):563-566. [PubMed: 16529622]

9. Begley CE, Beghi E, Beran RG, Heaney D, Langfitt JT, Pachlatko C, Silfvenius H, Sperling MR, Wiebe S. ILAE Commission on the Burden of Epilepsy, Subcommission on the Economic Burden of Epilepsy: final report 1998-2001. Epilepsia. 2002; 43(6):668-673. [PubMed: 12060034]

10. Bekelis K, Missios S, Desai A, Eskey C, Erkmen K. Magnetic resonance imaging/magnetic resonance angiography fusion technique for intraoperative navigation during microsurgical resection of cerebral arteriovenous malformations. Neurosurg Focus. 2012; 32(5):E7.

11. Berger MS. Minimalism through intraoperative functional mapping. Clin Neurosurg. 1996; 43:324-337. [PubMed: 9247814]

12. Berger MS, Ghatan S, Haglund MM, Dobbins J, Ojemann GA. Low-grade gliomas associated with intractable epilepsy: seizure outcome utilizing electrocorticography during tumor resection. $\mathrm{J}$ Neurosurg. 1993; 79(1):62-69. [PubMed: 8315470]

13. Berman JI, Berger MS, Chung SW, Nagarajan SS, Henry RG. Accuracy of diffusion tensor magnetic resonance imaging tractography assessed using intraoperative subcortical stimulation mapping and magnetic source imaging. J Neurosurg. 2007; 107(3):488-494. [PubMed: 17886545]

14. Bilginer B, Yalnizoglu D, Soylemezoglu F, Turanli G, Cila A, Topcu M, Akalan N. Surgery for epilepsy in children with dysembryoplastic neuroepithelial tumor: clinical spectrum, seizure outcome, neuroradiology, and pathology. Child's Nerv Syst ChNS : Off J Int Soc Pediatric Neurosurg. 2009; 25(4):485-491.

15. Bills D, Rosenfeld JV, Phelan EM, Klug GL. Intracranial arteriovenous malformations in childhood: presentation, management and outcome. J Clin Neurosci: Off J Neurosurg Soc Australas. 1996; 3(3):220-228. 
16. Binder JR. Functional MRI is a valid noninvasive alternative to Wada testing. Epilepsy Behav: E\&B. 2011; 20(2):214-222.

17. Bingaman WE. Surgery for focal cortical dysplasia. Neurology. 2004; 62(6 Suppl 3):S30-S34.

18. Blumcke I. Neuropathology of focal epilepsies: a critical review. Epilepsy Behav: E\&B. 2009; 15(1):34-39.

19. Blumcke I, Thom M, Aronica E, Armstrong DD, Vinters HV, Palmini A, Jacques TS, Avanzini G, Barkovich AJ, Battaglia G, Becker A, Cepeda C, Cendes F, Colombo N, Crino P, Cross JH, Delalande O, Dubeau F, Duncan J, Guerrini R, Kahane P, Mathern G, Najm I, Ozkara C, Raybaud C, Represa A, Roper SN, Salamon N, Schulze-Bonhage A, Tassi L, Vezzani A, Spreafico R. The clinicopathologic spectrum of focal cortical dysplasias: a consensus classification proposed by an ad hoc ask force of the ILAE Diagnostic Methods Commission. Epilepsia. 2011; 52(1):158-174. [PubMed: 21219302]

20. Bordey A, Sontheimer H. Properties of human glial cells associated with epileptic seizure foci. Epilepsy Res. 1998; 32(1-2):286-303. [PubMed: 9761328]

21. Bourneville D. Sclerose tubereuse des circonvolutions cerebrales: idiotie et epilepsie hemiplegique. Arch Neurol. 1880; 1:81-91.

22. Buckingham MJ, Crone KR, Ball WS, Berger TS. Management of cerebral cavernous angiomas in children presenting with seizures. Childs Nerv Syst: ChNS : Off J Int Soc Pediatr Neurosurg. 1989; 5(6):347-349.

23. Buckner JC. Factors influencing survival in high-grade gliomas. Semin Oncol. 2003; 30(6 Suppl 19):10-14.

24. Bujarski KA, Hirashima F, Roberts DW, Jobst BC, Gilbert KL, Roth RM, Flashman LA, McDonald BC, Saykin AJ, Scott RC, Dinnerstein E, Preston J, Williamson PD, Thadani VM. Long-term seizure, cognitive, and psychiatric outcome following trans-middle temporal gyrus amygdalohippocampectomy and standard temporal lobectomy. J Neurosurg. 2013; 119(1):16-23. [PubMed: 23621601]

25. Carlson C, Teutonico F, Elliott RE, Moshel YA, LaJoie J, Miles D, Devinsky O, Weiner HL. Bilateral invasive electroencephalography in patients with tuberous sclerosis complex: a path to surgery? J Neurosurg Pediatr. 2011; 7(4):421-430. [PubMed: 21456917]

26. Chaichana KL, Parker SL, Olivi A, Quinones-Hinojosa A. Long-term seizure outcomes in adult patients undergoing primary resection of malignant brain astrocytomas. Clinical article. $\mathrm{J}$ Neurosurg. 2009; 111(2):282-292. [PubMed: 19344222]

27. Chang EF, Christie C, Sullivan JE, Garcia PA, Tihan T, Gupta N, Berger MS, Barbaro NM. Seizure control outcomes after resection of dysembryoplastic neuroepithelial tumor in 50 patients. $\mathrm{J}$ Neurosurg Pediatr. 2010; 5(1):123-130. [PubMed: 20043747]

28. Chang EF, Clark A, Jensen RL, Bernstein M, Guha A, Carrabba G, Mukhopadhyay D, Kim W, Liau LM, Chang SM, Smith JS, Berger MS, McDermott MW. Multiinstitutional validation of the University of California at San Francisco Low-Grade Glioma Prognostic Scoring System. J Neurosurg. 2009; 111(2):203-210. [PubMed: 19267536]

29. Chang EF, Clark A, Smith JS, Polley MY, Chang SM, Barbaro NM, Parsa AT, McDermott MW, Berger MS. Functional mapping-guided resection of low-grade gliomas in eloquent areas of the brain: improvement of long-term survival. Clinical article. J Neurosurg. 2011; 114(3):566-573. [PubMed: 20635853]

30. Chang EF, Gabriel RA, Potts MB, Garcia PA, Barbaro NM, Lawton MT. Seizure characteristics and control after microsurgical resection of supratentorial cerebral cavernous malformations. Neurosurgery. 2009; 65(1):31-37. discussion 37-38. [PubMed: 19574823]

31. Chang EF, Nagarajan SS, Mantle M, Barbaro NM, Kirsch HE. Magnetic source imaging for the surgical evaluation of electroencephalography-confirmed secondary bilateral synchrony in intractable epilepsy. J Neurosurg. 2009; 111(6):1248-1256. [PubMed: 19575574]

32. Chang EF, Potts MB, Keles GE, Lamborn KR, Chang SM, Barbaro NM, Berger MS. Seizure characteristics and control following resection in 332 patients with low-grade gliomas. $\mathrm{J}$ Neurosurg. 2008; 108(2):227-235. [PubMed: 18240916] 
33. Chang EF, Wang DD, Barkovich AJ, Tihan T, Auguste KI, Sullivan JE, Garcia PA, Barbaro NM. Predictors of seizure freedom after surgery for malformations of cortical development. Ann Neurol. 2011; 70(1):151-162. [PubMed: 21761443]

34. Choi H, Sell RL, Lenert L, Muennig P, Goodman RR, Gilliam FG, Wong JB. Epilepsy surgery for pharmacoresistant temporal lobe epilepsy: a decision analysis. JAMA: J Am Med Assoc. 2008; 300(21):2497-2505.

35. Clusmann H, Kral T, Gleissner U, Sassen R, Urbach H, Blumcke I, Bogucki J, Schramm J. Analysis of different types of resection for pediatric patients with temporal lobe epilepsy. Neurosurgery. 2004; 54(4):847-859. discussion 859-860. [PubMed: 15046650]

36. Cohen-Gadol AA, Ozduman K, Bronen RA, Kim JH, Spencer DD. Long-term outcome after epilepsy surgery for focal cortical dysplasia. J Neurosurg. 2004; 101(1):55-65. [PubMed: 15255252]

37. Cook SW, Nguyen ST, Hu B, Yudovin S, Shields WD, Vinters HV, Van de Wiele BM, Harrison RE, Mathern GW. Cerebral hemispherectomy in pediatric patients with epilepsy: comparison of three techniques by pathological substrate in 115 patients. J Neurosurg. 2004; 100(2 Suppl):125141. Pediatrics.

38. Couillard-Despres S, Winkler J, Uyanik G, Aigner L. Molecular mechanisms of neuronal migration disorders, quo vadis? Curr Mol Med. 2001; 1(6):677-688. [PubMed: 11899256]

39. Crawford PM, West CR, Shaw MD, Chadwick DW. Cerebral arteriovenous malformations and epilepsy: factors in the development of epilepsy. Epilepsia. 1986; 27(3):270-275. [PubMed: 3698939]

40. Crino PB, Nathanson KL, Henske EP. The tuberous sclerosis complex. N Engl J Med. 2006; 355(13):1345-1356. [PubMed: 17005952]

41. Cross JH, Jayakar P, Nordli D, Delalande O, Duchowny M, Wieser HG, Guerrini R, Mathern GW. International League against Epilepsy, Subcommission for Pediatric Epilepsy Surgery, Commissions of Neurosurgery and Paediatrics. Proposed criteria for referral and evaluation of children for epilepsy surgery: recommendations of the Subcommission for Pediatric Epilepsy Surgery. Epilepsia. 2006; 47(6):952-959. [PubMed: 16822241]

42. Curran WJ Jr, Scott CB, Horton J, Nelson JS, Weinstein AS, Fischbach AJ, Chang CH, Rotman M, Asbell SO, Krisch RE, et al. Recursive partitioning analysis of prognostic factors in three Radiation Therapy Oncology Group malignant glioma trials. J Natl Cancer Inst. 1993; 85(9):704710. [PubMed: 8478956]

43. Cusmai R, Chiron C, Curatolo P, Dulac O, Tran-Dinh S. Topographic comparative study of magnetic resonance imaging and electroencephalography in 34 children with tuberous sclerosis. Epilepsia. 1990; 31(6):747-755. [PubMed: 2245805]

44. Cyberonics I. Cyberonics announces 100,000th patient implant of VNS therapy ${ }^{\circledR} .2012$ [Accessed December 20, 2012]

45. Dandy W. Removal of right cerebral hemisphere for certain tumors with hemiplegia. JAMA: J Am Med Assoc. 1928; 90:823-825.

46. de Lanerolle, NC., Lee, TS., Spencer, DD. Histopathology of human epilepsy. In: Noebels, JL.Avoli, M.Rogawski, MA.Olsen, RW., Delgado-Escueta, AV., editors. Jasper's basic mechanisms of the epilepsies. 4th. Bethesda, MD: 2012.

47. DeAngelis LM. Brain tumors. N Engl J Med. 2001; 344(2):114-123. [PubMed: 11150363]

48. DeFazio RA, Hablitz JJ. Alterations in NMDA receptors in a rat model of cortical dysplasia. J Neurophysiol. 2000; 83(1):315-321. [PubMed: 10634874]

49. Devinsky O. Diagnosis and treatment of temporal lobe epilepsy. Rev Neurol Dis. 2004; 1(1):2-9. [PubMed: 16397445]

50. Di Rocco C, Battaglia D, Pietrini D, Piastra M, Massimi L. Hemimegalencephaly: clinical implications and surgical treatment. Child's Nerv Syst: ChNS: Off J Int Soc Pediatr Neurosurg. 2006; 22(8):852-866.

51. Di Rocco C, Iannelli A. Hemimegalencephaly and intractable epilepsy: complications of hemispherectomy and their correlations with the surgical technique. A report on 15 cases. Pediatr Neurosurg. 2000; 33(4):198-207. [PubMed: 11124637] 
52. Dimou S, Battisti RA, Hermens DF, Lagopoulos J. A systematic review of functional magnetic resonance imaging and diffusion tensor imaging modalities used in presurgical planning of brain tumour resection. Neurosurg Rev. 2013; 36(2):205-214. [PubMed: 23187966]

53. Duffau H. Surgery of low-grade gliomas: towards a 'functional neurooncology'. Curr Opin Oncol. 2009; 21(6):543-549. [PubMed: 19606033]

54. Eisenschenk S, Gilmore RL, Friedman WA, Henchey RA. The effect of LINAC stereotactic radiosurgery on epilepsy associated with arteriovenous malformations. Stereotact Funct Neurosurg. 1998; 71(2):51-61. [PubMed: 10087469]

55. Elliott I, Kadis DS, Lach L, Olds J, McCleary L, Whiting S, Snyder T, Smith ML. Quality of life in young adults who underwent resective surgery for epilepsy in childhood. Epilepsia. 2012; 53(9): 1577-1586. [PubMed: 22812675]

56. Ellis MJ, Kulkarni AV, Drake JM, Rutka JT, Armstrong D, Dirks PB. Intraoperative angiography during microsurgical removal of arteriovenous malformations in children. J Neurosurg Pediatr. 2010; 6(5):435-443. [PubMed: 21039166]

57. Engel, J, Jr. Outcome with respect to epileptic seizures. In: Engel, J., Jr, editor. Surgical treatment of the epilepsies. New York: Raven; 1987. p. 553-571.

58. Engel J Jr. Surgery for seizures. N Engl J Med. 1996; 334(10):647-652. [PubMed: 8592530]

59. Engel J Jr. Finally, a randomized, controlled trial of epilepsy surgery. N Engl J Med. 2001; 345(5): 365-367. [PubMed: 11484695]

60. Engel J Jr. Surgical treatment for epilepsy: too little, too late? JAMA: J Am Med Assoc. 2008; 300(21):2548-2550.

61. Engel J Jr, McDermott MP, Wiebe S, Langfitt JT, Stern JM, Dewar S, Sperling MR, Gardiner I, Erba G, Fried I, Jacobs M, Vinters HV, Mintzer S, Kieburtz K. Early surgical therapy for drugresistant temporal lobe epilepsy: a randomized trial. JAMA: J Am Med Assoc. 2012; 307(9):922930.

62. Engel J Jr, Wiebe S. Who is a surgical candidate? Handb Clin Neurol. 2012; 108:821-828. [PubMed: 22939068]

63. Engel J Jr, Wiebe S, French J, Sperling M, Williamson P, Spencer D, Gumnit R, Zahn C, Westbrook E, Enos B. Practice parameter: temporal lobe and localized neocortical resections for epilepsy: report of the Quality Standards Subcommittee of the American Academy of Neurology, in association with the American Epilepsy Society and the American Association of Neurological Surgeons. Neurology. 2003; 60(4):538-547. [PubMed: 12601090]

64. Engel, J., Van Ness, P., Rasmussen, T., Ojemann, L. Outcome with respect to epileptic seizures. In: Engel, J., editor. Surgical treatment of the epilepsies. 2nd. New York: Raven; 1993. p. 609-621.

65. Engel, J., Williamson, PD. Limbic seizures. In: Engel, J., Pedley, TA., editors. Epilepsy: a comprehensive textbook. Philadelphia: Lippincott Williams \& Wilkins; 2007. p. 541-552.

66. Englot DJ, Berger MS, Barbaro NM, Chang EF. Predictors of seizure freedom after resection of supratentorial low-grade gliomas. A review. J Neurosurg. 2011; 115(2):240-244. [PubMed: 21529134]

67. Englot DJ, Berger MS, Chang EF, Garcia PA. Characteristics and treatment of seizures in patients with high-grade glioma: a review. Neurosurg Clin N Am. 2012; 23(2):227-235. [PubMed: 22440866]

68. Englot DJ, Blumenfeld H. Consciousness and epilepsy: why are complex-partial seizures complex? Prog Brain Res. 2009; 177:147-170. [PubMed: 19818900]

69. Englot DJ, Breshears JD, Sun PP, Chang EF, Auguste KI. Seizure outcomes after resective surgery for extra-temporal lobe epilepsy in pediatric patients. J Neurosurg Pediatr. 2013; 12(2):126-133. [PubMed: 23768201]

70. Englot DJ, Han SJ, Berger MS, Barbaro NM, Chang EF. Extent of surgical resection predicts seizure freedom in low-grade temporal lobe brain tumors. Neurosurgery. 2012; 70(4):921-928. [PubMed: 21997540]

71. Englot DJ, Han SJ, Lawton MT, Chang EF. Predictors of seizure freedom in the surgical treatment of supratentorial cavernous malformations. J Neurosurg. 2011; 115(6):1169-1174. [PubMed: 21819194] 
72. Englot DJ, Lee AT, Tsai C, Halabi C, Barbaro NM, Auguste KI, Garcia PA, Chang EF. Seizure types and frequency in patients who "fail" temporal lobectomy for intractable epilepsy. Neurosurgery. 2013; 73(5):838-844. [PubMed: 23892416]

73. Englot DJ, Ouyang D, Garcia PA, Barbaro NM, Chang EF. Epilepsy surgery trends in the United States, 1990-2008. Neurology. 2012; 78(16):1200-1206. [PubMed: 22442428]

74. Englot DJ, Ouyang D, Wang DD, Rolston JD, Garcia PA, Chang EF. Relationship between hospital surgical volume, lobectomy rates, and adverse perioperative events at US epilepsy centers. J Neurosurg. 2013; 118(1):169-174. [PubMed: 23101453]

75. Englot DJ, Rolston JD, Wang DD, Sun PP, Chang EF, Auguste KI. Seizure outcomes after temporal lobectomy in pediatric patients. J Neurosurg Pediatr. 2013; 12(2):134-141. [PubMed: 23768202]

76. Englot DJ, Rutkowski MJ, Ivan ME, Sun PP, Kuperman RA, Chang EF, Gupta N, Sullivan JE, Auguste KI. Effects of temporal lobectomy on consciousness-impairing and consciousness-sparing seizures in children. Childs Nerv Syst ChNS: Off J Int Soc Pediatr Neurosurg. 2013; 29(10):19151922.

77. Englot DJ, Wang DD, Rolston JD, Shih TT, Chang EF. Rates and predictors of long-term seizure freedom after frontal lobe epilepsy surgery: a systematic review and meta-analysis. J Neurosurg. 2012; 116(5):1042-1048. [PubMed: 22304450]

78. Englot DJ, Yang L, Hamid H, Danielson N, Bai X, Marfeo A, Yu L, Gordon A, Purcaro MJ, Motelow JE, Agarwal R, Ellens DJ, Golomb JD, Shamy MC, Zhang H, Carlson C, Doyle W, Devinsky O, Vives K, Spencer DD, Spencer SS, Schevon C, Zaveri HP, Blumenfeld H. Impaired consciousness in temporal lobe seizures: role of cortical slow activity. Brain J Neurol. 2010; 133(Pt 12):3764-3777.

79. Englot DJ, Young WL, Han SJ, McCulloch CE, Chang EF, Lawton MT. Seizure predictors and control after microsurgical resection of supratentorial arteriovenous malformations in 440 patients. Neurosurgery. 2012; 71(3):572-580. [PubMed: 22592327]

80. Evans LT, Morse R, Roberts DW. Epilepsy surgery in tuberous sclerosis: a review. Neurosurg Focus. 2012; 32(3):E5.

81. Fallah A, Guyatt GH, Snead OC 3rd, Ebrahim S, Ibrahim GM, Mansouri A, Reddy D, Walter SD, Kulkarni AV, Bhandari M, Banfield L, Bhatnagar N, Liang S, Teutonico F, Liao J, Rutka JT. Predictors of seizure outcomes in children with tuberous sclerosis complex and intractable epilepsy undergoing resective epilepsy surgery: an individual participant data meta-analysis. PloS One. 2013; 8(2):e53565. [PubMed: 23405072]

82. FDA. Device approvals and clearances. 2013 [Accessed March 30, 2013]

83. Ferrer I, Oliver B, Russi A, Casas R, Rivera R. Parvalbumin and calbindin-D28k immunocytochemistry in human neocortical epileptic foci. J Neurolog Sci. 1994; 123(1-2):18-25.

84. Fish DR, Spencer SS. Clinical correlations: MRI and EEG. Magn Reson Imaging. 1995; 13(8): 1113-1117. [PubMed: 8750324]

85. Flores-Sarnat L. Hemimegalencephaly: part 1. Genetic, clinical, and imaging aspects. J Child Neurol. 2002; 17(5):373-384. discussion 384. [PubMed: 12150586]

86. Fountas KN, Smith JR, Robinson JS, Tamburrini G, Pietrini D, Di Rocco C. Anatomical hemispherectomy. Childs Nerv Syst ChNS: Off J Int Soc Pediatr Neurosurg. 2006; 22(8):982-991.

87. French JA, Williamson PD, Thadani VM, Darcey TM, Mattson RH, Spencer SS, Spencer DD. Characteristics of medial temporal lobe epilepsy: I. Results of history and physical examination. Ann Neurol. 1993; 34(6):774-780. [PubMed: 8250525]

88. Fried I, Kim JH, Spencer DD. Limbic and neocortical gliomas associated with intractable seizures: a distinct clinicopathological group. Neurosurgery. 1994; 34(5):815-823. discussion 823-814. [PubMed: 8052378]

89. Fullerton HJ, Achrol AS, Johnston SC, McCulloch CE, Higashida RT, Lawton MT, Sidney S, Young WL. Long-term hemorrhage risk in children versus adults with brain arteriovenous malformations. Stroke. 2005; 36(10):2099-2104. [PubMed: 16141419]

90. Gerszten PC, Adelson PD, Kondziolka D, Flickinger JC, Lunsford LD. Seizure outcome in children treated for arteriovenous malformations using gamma knife radiosurgery. Pediatr Neurosurg. 1996; 24(3):139-144. [PubMed: 8870017] 
91. Gil-Nagel, A., Abou-Khalil, B. Electroencephalography and video-electroencephalography. In: Vinken, PJ., Bruyn, GW., editors. Handb Clin Neurol. Vol. 107. 2012. p. 323-345.

92. Giulioni M, Galassi E, Zucchelli M, Volpi L. Seizure outcome of lesionectomy in glioneuronal tumors associated with epilepsy in children. J Neurosurg. 2005; 102(3 Suppl):288-293. [PubMed: 15881752]

93. Giulioni M, Gardella E, Rubboli G, Roncaroli F, Zucchelli M, Bernardi B, Tassinari CA, Calbucci F. Lesionectomy in epileptogenic gangliogliomas: seizure outcome and surgical results. J Clin Neurosci: Off J Neurosurg Soc Australas. 2006; 13(5):529-535.

94. Giulioni M, Rubboli G, Marucci G, Martinoni M, Volpi L, Michelucci R, Marliani AF, Bisulli F, Tinuper P, Castana L, Sartori I, Calbucci F. Seizure outcome of epilepsy surgery in focal epilepsies associated with temporomesial glioneuronal tumors: lesionectomy compared with tailored resection. J Neurosurg. 2009; 111(6):1275-1282. [PubMed: 19408976]

95. Glantz MJ, Cole BF, Forsyth PA, Recht LD, Wen PY, Chamberlain MC, Grossman SA, Cairncross JG. Practice parameter: anticonvulsant prophylaxis in patients with newly diagnosed brain tumors. Report of the Quality Standards Subcommittee of the American Academy of Neurology. Neurology. 2000; 54(10):1886-1893. [PubMed: 10822423]

96. Goldstein LH, Polkey CE. Behavioural memory after temporal lobectomy or amygdalohippocampectomy. Br J Clin Psychol/ Br Psychol Soc. 1992; 31(Pt 1):75-81.

97. Goncalves-Ferreira A, Campos AR, Herculano-Carvalho M, Pimentel J, Bentes C, Peralta AR, Morgado C. Amygdalohippocampotomy: surgical technique and clinical results. J Neurosurg. 2013; 118(5):1107-1113. [PubMed: 23432145]

98. Gonzalez-Martinez JA, Gupta A, Kotagal P, Lachhwani D, Wyllie E, Luders HO, Bingaman WE. Hemispherectomy for catastrophic epilepsy in infants. Epilepsia. 2005; 46(9):1518-1525. [PubMed: 16146448]

99. Goodman M, Lamm SH, Engel A, Shepherd CW, Houser OW, Gomez MR. Cortical tuber count: a biomarker indicating neurologic severity of tuberous sclerosis complex. J Child Neurol. 1997; 12(2):85-90. [PubMed: 9075016]

100. Haglund MM, Berger MS, Kunkel DD, Franck JE, Ghatan S, Ojemann GA. Changes in gammaaminobutyric acid and somatostatin in epileptic cortex associated with low-grade gliomas. J Neurosurg. 1992; 77(2):209-216. [PubMed: 1352540]

101. Hammen T, Romstock J, Dorfler A, Kerling F, Buchfelder M, Stefan H. Prediction of postoperative outcome with special respect to removal of hemosiderin fringe: a study in patients with cavernous haemangiomas associated with symptomatic epilepsy. Seizure: J Br Epilepsy Assoc. 2007; 16(3):248-253.

102. Haneef Z, Stern J, Dewar S, Engel J Jr. Referral pattern for epilepsy surgery after evidence-based recommendations: a retrospective study. Neurology. 2010; 75(8):699-704. [PubMed: 20733145]

103. Hauptman JS, Mathern GW. Surgical treatment of epilepsy associated with cortical dysplasia: 2012 update. Epilepsia. 2012; 53(Suppl 4):98-104.

104. Heikkinen ER, Konnov B, Melnikov L, Yalynych N, Zubkov Yu N, Garmashov Yu A, Pak VA. Relief of epilepsy by radiosurgery of cerebral arteriovenous malformations. Stereotact Funct Neurosurg. 1989; 53(3):157-166. [PubMed: 2701035]

105. Helmstaedter C, Kockelmann E. Cognitive outcomes in patients with chronic temporal lobe epilepsy. Epilepsia. 2006; 47(Suppl 2):96-98. [PubMed: 17105474]

106. Herman ST. Epilepsy after brain insult: targeting epileptogenesis. Neurology. 2002; 59(9 Suppl 5):S21-S26.

107. Heros RC, Korosue K, Diebold PM. Surgical excision of cerebral arteriovenous malformations: late results. Neurosurgery. 1990; 26(4):570-577. discussion 577-578. [PubMed: 2330077]

108. Hilbig A, Babb TL, Najm I, Ying Z, Wyllie E, Bingaman W. Focal cortical dysplasia in children. Dev Neurosci. 1999; 21(3-5):271-280. [PubMed: 10575250]

109. Hogan RE, Kaiboriboon K. The "dreamy state”: John Hughlings-Jackson's ideas of epilepsy and consciousness. Am J Psychiatry. 2003; 160(10):1740-1747. [PubMed: 14514481]

110. Hoh BL, Chapman PH, Loeffler JS, Carter BS, Ogilvy CS. Results of multimodality treatment for 141 patients with brain arteriovenous malformations and seizures: factors associated with seizure 
incidence and seizure outcomes. Neurosurgery. 2002; 51(2):303-309. discussion 309-311. [PubMed: 12182768]

111. Hughlings-Jackson J, Stewart J. Epileptic attacks with a warning of a crude sensation of smell and with the intellectual aura (dreamy state) in a patient who had symptoms pointing to gross organic disease of the right temporo-sphenoidal lobe. Brain J Neurol. 1899; 22:534-543.

112. Jackson GD, Badawy RA. Selecting patients for epilepsy surgery: identifying a structural lesion. Epilepsy Behav: E\&B. 2011; 20(2):182-189.

113. Jansen FE, Huiskamp G, van Huffelen AC, Bourez-Swart M, Boere E, Gebbink T, Vincken KL, van Nieuwenhuizen O. Identification of the epileptogenic tuber in patients with tuberous sclerosis: a comparison of high-resolution EEG and MEG. Epilepsia. 2006; 47(1):108-114. [PubMed: 16417538]

114. Jansen FE, van Huffelen AC, Algra A, van Nieuwenhuizen O. Epilepsy surgery in tuberous sclerosis: a systematic review. Epilepsia. 2007; 48(8):1477-1484. [PubMed: 17484753]

115. Janszky J, Ebner A, Kruse B, Mertens M, Jokeit H, Seitz RJ, Witte OW, Tuxhorn I, Woermann FG. Functional organization of the brain with malformations of cortical development. Ann Neurol. 2003; 53(6):759-767. [PubMed: 12783422]

116. Jonas R, Nguyen S, Hu B, Asarnow RF, LoPresti C, Curtiss S, de Bode S, Yudovin S, Shields WD, Vinters HV, Mathern GW. Cerebral hemispherectomy: hospital course, seizure, developmental, language, and motor outcomes. Neurology. 2004; 62(10):1712-1721. [PubMed: 15159467]

117. Jooma R, Yeh HS, Privitera MD, Gartner M. Lesionectomy versus electrophysiologically guided resection for temporal lobe tumors manifesting with complex partial seizures. J Neurosurg. 1995; 83(2):231-236. [PubMed: 7616267]

118. Josephson CB, Leach JP, Duncan R, Roberts RC, Counsell CE, Al-Shahi Salman R. Scottish Audit of Intracranial Vascular Malformations (SAIVMs) Steering Committee and Collaborators. Seizure risk from cavernous or arteriovenous malformations: prospective population-based study. Neurology. 2011; 76(18):1548-1554. [PubMed: 21536634]

119. Kim JH, Guimaraes PO, Shen MY, Masukawa LM, Spencer DD. Hippocampal neuronal density in temporal lobe epilepsy with and without gliomas. Acta Neuropathol. 1990; 80(1):41-45. [PubMed: 2360416]

120. Kingwell K. Epilepsy: surgical therapy should not be considered a last resort for pharmacoresistant epilepsy. Nat Rev Neurol. 2012; 8(5):238.

121. Klein M, Engelberts NH, van der Ploeg HM, Kasteleijn-Nolst Trenite DG, Aaronson NK, Taphoorn MJ, Baaijen H, Vandertop WP, Muller M, Postma TJ, Heimans JJ. Epilepsy in lowgrade gliomas: the impact on cognitive function and quality of life. Ann Neurol. 2003; 54(4): 514-520. [PubMed: 14520665]

122. Kobayashi K, Ohtsuka Y, Ohno S, Ohmori I, Ogino T, Yoshinaga H, Tanaka A, Hiraki Y, Oka E. Clinical spectrum of epileptic spasms associated with cortical malformation. Neuropediatrics. 2001; 32(5):236-244. [PubMed: 11748494]

123. Kondziolka D, Humphreys RP, Hoffman HJ, Hendrick EB, Drake JM. Arteriovenous malformations of the brain in children: a forty year experience. Can J Neurol Sci. 1992; 19(1): 40-45. [PubMed: 1562906]

124. Kondziolka D, Lunsford LD, Kestle JR. The natural history of cerebral cavernous malformations. J Neurosurg. 1995; 83(5):820-824. [PubMed: 7472549]

125. Kraemer DL, Awad IA. Vascular malformations and epilepsy: clinical considerations and basic mechanisms. Epilepsia. 1994; 35(Suppl 6):S30-S43.

126. Kwan P, Brodie MJ. Early identification of refractory epilepsy. N Engl J Med. 2000; 342(5):314319. [PubMed: 10660394]

127. Kwan P, Sperling MR. Refractory seizures: try additional antiepileptic drugs (after two have failed) or go directly to early surgery evaluation? Epilepsia. 2009; 50(Suppl 8):57-62. [PubMed: 19702735]

128. Labiner DM, Bagic AI, Herman ST, Fountain NB, Walczak TS, Gumnit RJ, National Association of Epilepsy C. Essential services, personnel, and facilities in specialized epilepsy centersrevised 2010 guidelines. Epilepsia. 2010; 51(11):2322-2333. [PubMed: 20561026] 
129. Leblanc R, Feindel W, Ethier R. Epilepsy from cerebral arteriovenous malformations. Can J Neurol Sci. 1983; 10(2):91-95. [PubMed: 6861014]

130. Leventer RJ, Guerrini R, Dobyns WB. Malformations of cortical development and epilepsy. Dialogues Clin Neurosci. 2008; 10(1):47-62. [PubMed: 18472484]

131. Luyken C, Blumcke I, Fimmers R, Urbach H, Elger CE, Wiestler OD, Schramm J. The spectrum of long-term epilepsy-associated tumors: long-term seizure and tumor outcome and neurosurgical aspects. Epilepsia. 2003; 44(6):822-830. [PubMed: 12790896]

132. Macrodimitris S, Sherman EM, Williams TS, Bigras C, Wiebe S. Measuring patient satisfaction following epilepsy surgery. Epilepsia. 2011; 52(8):1409-1417. [PubMed: 21762442]

133. Marcotte L, Crino PB. The neurobiology of the tuberous sclerosis complex. Neuromol Med. 2006; 8(4):531-546.

134. Martino J, Honma SM, Findlay AM, Guggisberg AG, Owen JP, Kirsch HE, Berger MS, Nagarajan SS. Resting functional connectivity in patients with brain tumors in eloquent areas. Ann Neurol. 2011; 69(3):521-532. [PubMed: 21400562]

135. McKenzie K. The present status of a patient who had the right cerebral hemisphere removed. JAMA: J Am Med Assoc. 1938; 111:168.

136. Mengesha T, Abu-Ata M, Haas KF, Lavin PJ, Sun DA, Konrad PE, Pearson M, Wang L, Song Y, Abou-Khalil BW. Visual field defects after selective amygdalohippocampectomy and standard temporal lobectomy. J NeuroOphthalmol: Off J N American NeuroOphthalmol Soc. 2009; 29(3): 208-213.

137. Milandre L, Pellissier JF, Boudouresques G, Bonnefoi B, Ali Cherif A, Khalil R. Non-hereditary multiple telangiectasias of the central nervous system. Report of two clinicopathological cases. J Neurol Sci. 1987; 82(1-3):291-304. [PubMed: 3440871]

138. Moosa AN, Gupta A, Jehi L, Marashly A, Cosmo G, Lachhwani D, Wyllie E, Kotagal P, Bingaman W. Longitudinal seizure outcome and prognostic predictors after hemispherectomy in 170 children. Neurology. 2013; 80(3):253-260. [PubMed: 23223541]

139. Moots PL, Maciunas RJ, Eisert DR, Parker RA, Laporte K, Abou-Khalil B. The course of seizure disorders in patients with malignant gliomas. Arch Neurol. 1995; 52(7):717-724. [PubMed: 7619029]

140. Moran NF, Fish DR, Kitchen N, Shorvon S, Kendall BE, Stevens JM. Supratentorial cavernous haemangiomas and epilepsy: a review of the literature and case series. J Neurol Neurosurg Psychiatry. 1999; 66(5):561-568. [PubMed: 10209164]

141. Moreno A, de Felipe J, Garcia Sola R, Navarro A, Ramon y, Cajal S. Neuronal and mixed neuronal glial tumors associated to epilepsy. A heterogeneous and related group of tumours. Histol Histopathol. 2001; 16(2):613-622. [PubMed: 11332717]

142. Morino M, Uda T, Naito K, Yoshimura M, Ishibashi K, Goto T, Ohata K, Hara M. Comparison of neuropsychological outcomes after selective amygdalohippocampectomy versus anterior temporal lobectomy. Epilepsy Behav: E\&B. 2006; 9(1):95-100.

143. Murphy MJ. Long-term follow-up of seizures associated with cerebral arteriovenous malformations. Results of therapy. Arch Neurol. 1985; 42(5):477-479. [PubMed: 3994565]

144. Nagata S, Morioka T, Matsukado K, Natori Y, Sasaki T. Retrospective analysis of the surgically treated temporal lobe arteriovenous malformations with focus on the visual field defects and epilepsy. Surg Neurol. 2006; 66(1):50-55. discussion 55. [PubMed: 16793441]

145. Nakaji P, Spetzler RF. Indications for surgical treatment of arteriovenous malformations. Neurosurg Clin N Am. 2005; 16(2):365-366. [PubMed: 15694167]

146. O’Brien DF, Basu S, Williams DH, May PL. Anatomical hemispherectomy for intractable seizures: excellent seizure control, low morbidity and no superficial cerebral haemosiderosis. Childs Nerv Syst: ChNS: Off J Int Soc Pediatr Neurosurg. 2006; 22(5):489-498. discussion 499.

147. O'Brien DF, Farrell M, Delanty N, Traunecker H, Perrin R, Smyth MD, Park TS. The Children's Cancer and Leukaemia Group guidelines for the diagnosis and management of dysembryoplastic neuroepithelial tumours. Br J Neurosurg. 2007; 21(6):539-549. [PubMed: 18071981]

148. Ogiwara H, Nordli DR, DiPatri AJ, Alden TD, Bowman RM, Tomita T. Pediatric epileptogenic gangliogliomas: seizure outcome and surgical results. J Neurosurg Pediatr. 2010; 5(3):271-276. [PubMed: 20192644] 
149. Ojemann RG, Ogilvy CS. Microsurgical treatment of supratentorial cavernous malformations. Neurosurg Clin N Am. 1999; 10(3):433-440. [PubMed: 10419570]

150. Ondra SL, Troupp H, George ED, Schwab K. The natural history of symptomatic arteriovenous malformations of the brain: a 24-year follow-up assessment. J Neurosurg. 1990; 73(3):387-391. [PubMed: 2384776]

151. Palmini A, Najm I, Avanzini G, Babb T, Guerrini R, Foldvary-Schaefer N, Jackson G, Luders HO, Prayson R, Spreafico R, Vinters HV. Terminology and classification of the cortical dysplasias. Neurology. 2004; 62(6 Suppl 3):S2-S8.

152. Park YS, Kim DS, Shim KW, Kim JH, Choi JU. Factors contributing to resectability and seizure outcomes in 44 patients with ganglioglioma. Clin Neurol Neurosurg. 2008; 110(7):667-673. [PubMed: 18499337]

153. Parrent AG, Blume WT. Stereotactic amygdalohippocampotomy for the treatment of medial temporal lobe epilepsy. Epilepsia. 1999; 40(10):1408-1416. [PubMed: 10528937]

154. Pasquier B, Peoc HM, Fabre-Bocquentin B, Bensaadi L, Pasquier D, Hoffmann D, Kahane P, Tassi L, Le Bas JF, Benabid AL. Surgical pathology of drug-resistant partial epilepsy. A 10-yearexperience with a series of 327 consecutive resections. Epileptic Disord. 2002; 4(2):99-119. [PubMed: 12105073]

155. Phi JH, Chung CK. Brain tumors in the mesial temporal lobe: long-term oncological outcome. Neurosurg Focus. 2009; 27(2):E5.

156. Phi JH, Kim SK, Cho BK, Lee SY, Park SY, Park SJ, Lee SK, Kim KJ, Chung CK. Long-term surgical outcomes of temporal lobe epilepsy associated with low-grade brain tumors. Cancer. 2009; 115(24):5771-5779. [PubMed: 19806640]

157. Piepgras DG, Sundt TM Jr, Ragoowansi AT, Stevens L. Seizure outcome in patients with surgically treated cerebral arteriovenous malformations. J Neurosurg. 1993; 78(1):5-11. [PubMed: 8416242]

158. Pignatti F, van den Bent M, Curran D, Debruyne C, Sylvester R, Therasse P, Afra D, Cornu P, Bolla M, Vecht C, Karim AB, European Organization for R, Treatment of Cancer Brain Tumor Cooperative G, European Organization for R, Treatment of Cancer Radiotherapy Cooperative G. Prognostic factors for survival in adult patients with cerebral low-grade glioma. J Clin Oncol: Off J Am Soc Clin Oncol. 2002; 20(8):2076-2084.

159. Rasmussen T. Postoperative superficial hemosiderosis of the brain, its diagnosis, treatment and prevention. Trans Am Neurol Assoc. 1973; 98:133-137. [PubMed: 4784920]

160. Recht, L., Glantz, M. Neoplastic diseases. In: Engel, J., Jr, Pedley, T., editors. Epilepsy: a comprehensive textbook. New York: Lippincott, Williams, and Wilkins; 2008. p. 2637-2642.

161. Ritaccio A, Beauchamp M, Bosman C, Brunner P, Chang E, Crone N, Gunduz A, Gupta D, Knight R, Leuthardt E, Litt B, Moran D, Ojemann J, Parvizi J, Ramsey N, Rieger J, Viventi J, Voytek B, Williams J, Schalk G. Proceedings of the Third International Workshop on Advances in Electrocorticography. Epilepsy Behav: E\&B. 2012; 25(4):605-613.

162. Robinson JR, Awad IA, Little JR. Natural history of the cavernous angioma. J Neurosurg. 1991; 75(5):709-714. [PubMed: 1919692]

163. Robinson JR Jr, Awad IA, Masaryk TJ, Estes ML. Pathological heterogeneity of angiographically occult vascular malformations of the brain. Neurosurgery. 1993; 33(4):547-554. discussion 554545. [PubMed: 8232794]

164. Romanelli P, Weiner HL, Najjar S, Devinsky O. Bilateral resective epilepsy surgery in a child with tuberous sclerosis: case report. Neurosurgery. 2001; 49(3):732-734. discussion 735. [PubMed: 11523687]

165. Roper SN. Surgical treatment of the extratemporal epilepsies. Epilepsia. 2009; 50(Suppl 8):6974.

166. Rosati A, Marconi S, Pollo B, Tomassini A, Lovato L, Maderna E, Maier K, Schwartz A, Rizzuto N, Padovani A, Bonetti B. Epilepsy in glioblastoma multiforme: correlation with glutamine synthetase levels. J Neurooncol. 2009; 93(3):319-324. [PubMed: 19183851]

167. Ross J, Al-Shahi Salman R. Interventions for treating brain arteriovenous malformations in adults. Cochrane Database Syst Rev. 2010; 7:CD003436. 
168. Rowland NC, Englot DJ, Cage TA, Sughrue ME, Barbaro NM, Chang EF. A meta-analysis of predictors of seizure freedom in the surgical management of focal cortical dysplasia. $\mathrm{J}$ Neurosurg. 2012; 116(5):1035-1041. [PubMed: 22324422]

169. Ruda R, Trevisan E, Soffietti R. Epilepsy and brain tumors. Curr Opin Oncol. 2010; 22(6):611620. [PubMed: 20706121]

170. Ryvlin P, Mauguiere F, Sindou M, Froment JC, Cinotti L. Interictal cerebral metabolism and epilepsy in cavernous angiomas. Brain: J Neurol. 1995; 118(Pt 3):677-687.

171. Sanai N, Mirzadeh Z, Berger MS. Functional outcome after language mapping for glioma resection. N Engl J Med. 2008; 358(1):18-27. [PubMed: 18172171]

172. Scheidegger O, Wiest R, Jann K, Konig T, Meyer K, Hauf M. Epileptogenic developmental venous anomaly: insights from simultaneous EEG/fMRI. Clin EEG Neurosci. 2013; 44(2):157160. [PubMed: 23396079]

173. Schiltz NK, Koroukian SM, Lhatoo SD, Kaiboriboon K. Temporal trends in pre-surgical evaluations and epilepsy surgery in the U.S. from 1998 to 2009. Epilepsy Res. 2013; 103(2-3): 270-278. [PubMed: 22858308]

174. Schomer DL, Lewis RJ. Stopping seizures early and the surgical epilepsy trial that stopped even earlier. JAMA: J Am Med Assoc. 2012; 307(9):966-968.

175. Schramm J. Temporal lobe epilepsy surgery and the quest for optimal extent of resection: a review. Epilepsia. 2008; 49(8):1296-1307. [PubMed: 18410360]

176. Schramm J, Kuczaty S, Sassen R, Elger CE, von Lehe M. Pediatric functional hemispherectomy: outcome in 92 patients. Acta Neurochir (Wien). 2012; 154(11):2017-2028. [PubMed: 22941395]

177. Senft C, Bink A, Franz K, Vatter H, Gasser T, Seifert V. Intraoperative MRI guidance and extent of resection in glioma surgery: a randomised, controlled trial. Lancet Oncol. 2011; 12(11):9971003. [PubMed: 21868284]

178. Shamji MF, Fric-Shamji EC, Benoit BG. Brain tumors and epilepsy: pathophysiology of peritumoral changes. Neurosurg Rev. 2009; 32(3):275-284. discussion 284-276. [PubMed: 19205766]

179. Sheth RD. Adolescent issues in epilepsy. J Child Neurol. 2002; 17(Suppl 2):2S23-22S27. [PubMed: 11952033]

180. Sims J. On the hypertrophy and atrophy of the brain. Medicochirurgical Trans R Med Chir Soc (London). 1835; 19:315-380.

181. Southwell DG, Garcia PA, Berger MS, Barbaro NM, Chang EF. Long-term seizure control outcomes after resection of gangliogliomas. Neurosurgery. 2012; 70(6):1406-1413. discussion 1413-1404. [PubMed: 22353798]

182. Spencer S, Huh L. Outcomes of epilepsy surgery in adults and children. Lancet Neurol. 2008; 7(6):525-537. [PubMed: 18485316]

183. Spreafico R, Tassi L, Colombo N, Bramerio M, Galli C, Garbelli R, Ferrario A, Lo Russo G, Munari C. Inhibitory circuits in human dysplastic tissue. Epilepsia. 2000; 41(Suppl 6):S168S173. [PubMed: 10999539]

184. Stavrou I, Baumgartner C, Frischer JM, Trattnig S, Knosp E. Long-term seizure control after resection of supratentorial cavernomas: a retrospective single-center study in 53 patients. Neurosurgery. 2008; 63(5):888-896. discussion 897. [PubMed: 19005379]

185. Tang SC, Jeng JS, Liu HM, Yip PK. Diffuse capillary telangiectasia of the brain manifested as a slowly progressive course. Cerebrovasc Dis. 2003; 15(1-2):140-142. [PubMed: 12499724]

186. Taphoorn MJ. Neurocognitive sequelae in the treatment of low-grade gliomas. Semin Oncol. 2003; 30(6 Suppl 19):45-48. [PubMed: 14765385]

187. Taphoorn MJ, Klein M. Cognitive deficits in adult patients with brain tumours. Lancet Neurol. 2004; 3(3):159-168. [PubMed: 14980531]

188. Thapa A, Chandra PS, Sinha S, Gupta A, Singh M, Suri A, Sharma BS. Surgical interventions in intracranial arteriovenous malformations: indications and outcome analysis in a changing scenario. Neurol India. 2009; 57(6):749-755. [PubMed: 20139504]

189. Thom M. Hippocampal sclerosis: progress since Sommer. Brain Pathol. 2009; 19(4):565-572. [PubMed: 18761661] 
190. Thom M, Mathern GW, Cross JH, Bertram EH. Mesial temporal lobe epilepsy: how do we improve surgical outcome? Ann Neurol. 2010; 68(4):424-434. [PubMed: 20976764]

191. Thorpe ML, Cordato DJ, Morgan MK, Herkes GK. Postoperative seizure outcome in a series of 114 patients with supratentorial arteriovenous malformations. J Clin Neurosci: Off J Neurosurg Soc Australas. 2000; 7(2):107-111.

192. Thudium MO, Campos AR, Urbach H, Clusmann H. The basal temporal approach for mesial temporal surgery: sparing the Meyer loop with navigated diffusion tensor tractography. Neurosurgery. 2010; 67(2 Suppl):385-390. Operative. [PubMed: 21099562]

193. Tinkle BT, Schorry EK, Franz DN, Crone KR, Saal HM. Epidemiology of hemimegalencephaly: a case series and review. Am J Med Genet A. 2005; 139(3):204-211. [PubMed: 16283674]

194. Tonini C, Beghi E, Berg AT, Bogliun G, Giordano L, Newton RW, Tetto A, Vitelli E, Vitezic D, Wiebe S. Predictors of epilepsy surgery outcome: a meta-analysis. Epilepsy Res. 2004; 62(1):7587. [PubMed: 15519134]

195. Villanueva V, Codina M, Elices E. Management of epilepsy in oncological patients. Neurologist. 2008; 14(6 Suppl 1):S44-S54. [PubMed: 19225370]

196. von Essen C, Rydenhag B, Nystrom B, Mozzi R, van Gelder N, Hamberger A. High levels of glycine and serine as a cause of the seizure symptoms of cavernous angiomas? J Neurochem. 1996; 67(1):260-264. [PubMed: 8667000]

197. Wachi M, Tomikawa M, Fukuda M, Kameyama S, Kasahara K, Sasagawa M, Shirane S, Kanazawa O, Yoshino M, Aoki S, Sohma Y. Neuropsychological changes after surgical treatment for temporal lobe epilepsy. Epilepsia. 2001; 42(Suppl 6):4-8.

198. Wang DD, Deans AE, Barkovich AJ, Tihan T, Barbaro NM, Garcia PA, Chang EF. Transmantle sign in focal cortical dysplasia: a unique radiological entity with excellent prognosis for seizure control. J Neurosurg. 2013; 118(2):337-344. [PubMed: 23216463]

199. Wang VY, Chang EF, Barbaro NM. Focal cortical dysplasia: a review of pathological features, genetics, and surgical outcome. Neurosurg Focus. 2006; 20(1):E7.

200. Washington CW, McCoy KE, Zipfel GJ. Update on the natural history of cavernous malformations and factors predicting aggressive clinical presentation. Neurosurgical Focus. 2010; 29(3):E7.

201. Westerveld M, Sass KJ, Chelune GJ, Hermann BP, Barr WB, Loring DW, Strauss E, Trenerry MR, Perrine K, Spencer DD. Temporal lobectomy in children: cognitive outcome. J Neurosurg. 2000; 92(1):24-30.

202. Westmoreland, B. The electroencephalogram in tuberous sclerosis. In: Rodriguez-Gomez, M.Sampson, J., Whittemore, V., editors. Tubrous sclerosis complex: developmental perspectives in psychiatry. 3rd. New York: Oxford University Press; 1999. p. 63-73.

203. White JC, Liu CT, Mixter WJ. Focal epilepsy; a statistical study of its causes and the results of surgical treatment; epilepsy secondary to intracranial tumors. N Engl J Med. 1948; 238(26):891899. [PubMed: 18864487]

204. White R, Hua Y, Scheithauer B, Lynch DR, Henske EP, Crino PB. Selective alterations in glutamate and GABA receptor subunit mRNA expression in dysplastic neurons and giant cells of cortical tubers. Ann Neurol. 2001; 49(1):67-78. [PubMed: 11198298]

205. Wiebe S. Effectiveness and safety of epilepsy surgery: what is the evidence? CNS Spectr. 2004; 9(2):120-122. 126-132. [PubMed: 14999168]

206. Wiebe S, Berg AT. Big epilepsy surgery for little people: what's the full story on hemispherectomy? Neurology. 2013; 80(3):232-233. [PubMed: 23223536]

207. Wiebe S, Blume WT, Girvin JP, Eliasziw M. A randomized, controlled trial of surgery for temporal-lobe epilepsy. N Engl J Med. 2001; 345(5):311-318. [PubMed: 11484687]

208. Wilkins RH. Natural history of intracranial vascular malformations: a review. Neurosurgery. 1985; 16(3):421-430. [PubMed: 3885072]

209. Williamson A, Patrylo PR, Lee S, Spencer DD. Physiology of human cortical neurons adjacent to cavernous malformations and tumors. Epilepsia. 2003; 44(11):1413-1419. [PubMed: 14636349]

210. Wilson SJ, Engel J Jr. Diverse perspectives on developments in epilepsy surgery. Seizure: J Br Epilepsy Assoc. 2010; 19(10):659-668. 
211. Wolf HK, Roos D, Blumcke I, Pietsch T, Wiestler OD. Perilesional neurochemical changes in focal epilepsies. Acta Neuropathol. 1996; 91(4):376-384. [PubMed: 8928614]

212. Wolf RL, Ivnik RJ, Hirschorn KA, Sharbrough FW, Cascino GD, Marsh WR. Neurocognitive efficiency following left temporal lobectomy: standard versus limited resection. J Neurosurg. 1993; 79(1):76-83. [PubMed: 8315472]

213. Wong M, Ess KC, Uhlmann EJ, Jansen LA, Li W, Crino PB, Mennerick S, Yamada KA, Gutmann DH. Impaired glial glutamate transport in a mouse tuberous sclerosis epilepsy model. Ann Neurol. 2003; 54(2):251-256. [PubMed: 12891680]

214. Yang I, Chang EF, Han SJ, Barry JJ, Fang S, Tihan T, Barbaro NM, Parsa AT. Early surgical intervention in adult patients with ganglioglioma is associated with improved clinical seizure outcomes. J Clin Neurosci: Off J Neurosurg Soc Australas. 2011; 18(1):29-33.

215. Yasargil MG, Krayenbuhl N, Roth P, Hsu SP, Yasargil DC. The selective amygdalohippocampectomy for intractable temporal limbic seizures. J Neurosurg. 2010; 112(1): 168-185. [PubMed: 19575575]

216. Yeh HS, Privitera MD. Secondary epileptogenesis in cerebral arteriovenous malformations. Arch Neurol. 1991; 48(11):1122-1124. [PubMed: 1953394]

217. Yeh HS, Tew TM Jr, Gartner M. Seizure control after surgery on cerebral arteriovenous malformations. J Neurosurg. 1993; 78(1):12-18. [PubMed: 8416226]

218. Yeon JY, Kim JS, Choi SJ, Seo DW, Hong SB, Hong SC. Supratentorial cavernous angiomas presenting with seizures: surgical outcomes in 60 consecutive patients. Seizure: J Br Epilepsy Assoc. 2009; 18(1):14-20.

219. You G, Sha ZY, Yan W, Zhang W, Wang YZ, Li SW, Sang L, Wang Z, Li GL, Li SW, Song YJ, Kang CS, Jiang T. Seizure characteristics and outcomes in 508 Chinese adult patients undergoing primary resection of low-grade gliomas: a clinicopathological study. Neuro-oncology. 2012; 14(2):230-241. [PubMed: 22187341]

220. Yuan J, Chen Y, Hirsch E. Intracranial electrodes in the presurgical evaluation of epilepsy. Neurol Sci. 2012; 33(4):723-729. [PubMed: 22460695]

221. Zaatreh MM, Firlik KS, Spencer DD, Spencer SS. Temporal lobe tumoral epilepsy: characteristics and predictors of surgical outcome. Neurology. 2003; 61(5):636-641. [PubMed: 12963754]

222. Zevgaridis D, van Velthoven V, Ebeling U, Reulen HJ. Seizure control following surgery in supratentorial cavernous malformations: a retrospective study in 77 patients. Acta Neurochir (Wien). 1996; 138(6):672-677. [PubMed: 8836281] 


\section{를}

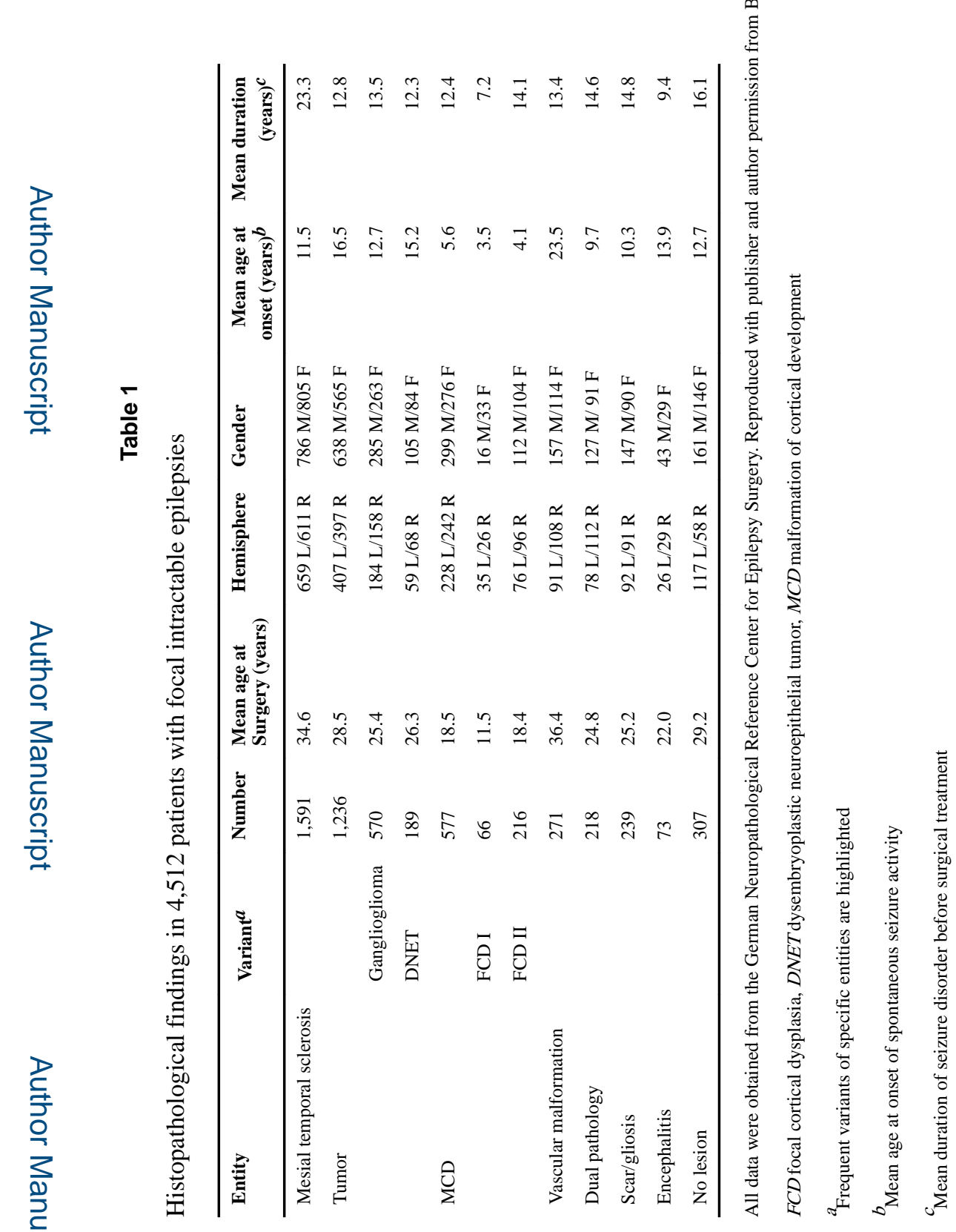

Neurosurg Rev. Author manuscript; available in PMC 2017 January 23. 


\section{Table 2}

Three-tiered ILAE classification system of FCD distinguishes isolated forms (FCD types I and II) from those associated with another principal lesion (FCD type III)

\begin{tabular}{llll}
\hline FCD type I (isolated) & $\begin{array}{l}\text { Focal cortical dysplasia with } \\
\text { abnormal radial cortical } \\
\text { lamination (FCD type Ia) }\end{array}$ & $\begin{array}{l}\text { Focal cortical dysplasia with } \\
\text { abnormal tangential cortical } \\
\text { lamination (FCD type Ib) }\end{array}$ & $\begin{array}{l}\text { Focal cortical dysplasia with } \\
\text { abnormal radial and tangential } \\
\text { cortical lamination (FCD type Ic) }\end{array}$ \\
$\begin{array}{l}\text { FCD type II } \\
\text { (isolated) }\end{array}$ & $\begin{array}{l}\text { Focal cortical dysplasia } \\
\text { with dysmorphic } \\
\text { neurons (FCD type IIa) }\end{array}$ & $\begin{array}{l}\text { Focal cortical dysplasia with } \\
\text { dysmorphic neurons and } \\
\text { balloon cells (FCD type IIb) }\end{array}$ \\
$\begin{array}{l}\text { FCD type III } \\
\begin{array}{l}\text { (associated } \\
\text { with principal lesion) }\end{array}\end{array}$ & $\begin{array}{l}\text { FCD type III (associated } \\
\text { with principal lesion) }\end{array}$ & $\begin{array}{l}\text { Cortical lamination } \\
\text { abnormalities } \\
\text { in the temporal lobe associated } \\
\text { with hippocampal sclerosis } \\
\text { (FCD type IIIa) }\end{array}$ & $\begin{array}{l}\text { Cortical lamination anormalities adjacent abnormalities adjacent to } \\
\text { abo glial or glioneuronal vascular malformation } \\
\text { tumor (FCD type IIIb) (FCD type IIIc) }\end{array}$ \\
\hline
\end{tabular}

FCD type III (not otherwise specified): if clinically/radiologically suspected principal lesion is not available for microscopic inspection. Please note that the rare association between FCD types IIa and IIb with hippocampal sclerosis, tumors, or vascular malformations should not be classified as FCD type III variant. Reprinted with permission from Blümcke et al. [19] 
Table 3

Seizure freedom and outcome predictors in resective epilepsy surgery

\begin{tabular}{|c|c|c|c|c|}
\hline Epilepsy etiology/cause & Specific pathology & $\begin{array}{l}\text { Engel class I } \\
\text { outcome }\end{array}$ & Predictors of favorable outcome & References included \\
\hline $\begin{array}{l}\text { Mesial temporal lobe } \\
\text { epilepsy }\end{array}$ & $\begin{array}{l}\text { Mesial temporal sclerosis } \\
\text { and other causes }\end{array}$ & $58-73 \%^{a}$ & $\begin{array}{l}\text { Febrile seizures, mesial temporal } \\
\text { sclerosis, abnormal MRI, tumor, } \\
\text { EEG/MRI concordance }\end{array}$ & {$[61,63,194,207]$} \\
\hline \multirow[t]{2}{*}{ Tumor } & Glioneuronal tumor & $72-80 \% b$ & $\begin{array}{l}\text { Early intervention, gross total resection, } \\
\text { lack of generalized seizures }\end{array}$ & {$[67,214]$} \\
\hline & Low grade glioma & $67 \% b$ & Gross total resection, early intervention & {$[66]$} \\
\hline \multirow[t]{3}{*}{$\begin{array}{l}\text { Malformation of cortical } \\
\text { development }\end{array}$} & Focal cortical dysplasia & $58 \% b$ & $\begin{array}{l}\text { Gross total resection, lack of generalized } \\
\text { seizures, temporal location, abnormal } \\
\text { MRI, type II classification }\end{array}$ & [168] \\
\hline & Tuberous sclerosis & $56-57 \% b$ & $\begin{array}{l}\text { Lack of intellectual disability, lack of } \\
\text { generalized seizures, localized ictal } \\
\text { EEG, EEG/MRI concordance }\end{array}$ & {$[81,114]$} \\
\hline & $\begin{array}{l}\text { Severe hemispheric epilepsy } \\
\text { (hemispherectomy) }\end{array}$ & $66-85 \% c$ & $\begin{array}{l}\text { Early intervention, young age, } \\
\text { Sturge-Weber, lack of } \\
\text { hemimegalencephaly, } \\
\text { unilateral PET abnormality }\end{array}$ & {$[2,138,176]$} \\
\hline \multirow[t]{2}{*}{ Vascular malformation } & Cavernous malformation & $75 \% b$ & $\begin{array}{l}\text { Gross total resection, early intervention, } \\
\text { small lesion, single lesion, lack of } \\
\text { generalized seizures }\end{array}$ & {$[71]$} \\
\hline & Arteriovenous malformation & $70-91 \% c$ & $\begin{array}{l}\text { Early intervention, young age, gross } \\
\text { total obliteration, lack of deep artery } \\
\text { perforators }\end{array}$ & {$[79,191,217]$} \\
\hline
\end{tabular}

Neurosurg Rev. Author manuscript; available in PMC 2017 January 23. 